\author{
UNIVERSIDADE DE SÃO PAULO \\ FACULDADE DE ODONTOLOGIA DE RIBEIRÃO PRETO
}

PATRICIA COSTA CRUZ

Avaliação clínica da eficácia dos métodos químico (peróxido alcalino) e mecânico (ultra-som) frente à propriedade de remoção do biofilme de próteses totais 


\section{Avaliação clínica da eficácia dos métodos químico (peróxido alcalino) e mecânico (ultra-som) frente à propriedade de remoção de biofilme de próteses totais}

Dissertação apresentada à Faculdade de Odontologia de Ribeirão Preto da Universidade de São Paulo para obtenção do título de Mestre em Odontologia.

Área de Concentração: Reabilitação Oral

Orientador: Profa. Dra. Helena de Freitas Oliveira Paranhos 
Autorizo a reprodução ou divulgação total ou parcial deste trabalho, por qualquer meio convencional ou eletrônico, para fins de estudo e pesquisa, desde que citada a fonte.

\section{FICHA CATALOGRÁFICA}

\section{Cruz, Patricia Costa}

Avaliação clínica da efetividade dos métodos químico (peróxido alcalino) e mecânico (ultra-som) frente à propriedade de remoção de biofilme de próteses totais. Ribeirão Preto, 2007.

72 p.: il.;30cm

Dissertação de Mestrado apresentada à Faculdade de Odontologia de Ribeirão Preto / USP - Depto. de Materiais Dentários e Prótese Área de Concentração: Reabilitação Oral.

Orientador: Paranhos, Helena de Freitas Oliveira

1. Prótese Total; 2. Biofilme; 3. Higienizadores de Próteses Totais. 


\section{FOLHA DE APROVAÇÃO}

\section{Patricia Costa Cruz}

Avaliação clínica da eficácia dos métodos químico (peróxido alcalino) e mecânico (ultra-som) frente à propriedade de remoção do biofilme de próteses totais.

Dissertação apresentada à Faculdade de Odontologia de Ribeirão Preto da Universidade de São Paulo para obtenção do título de Mestre.

Área de Concentração: Reabilitação Oral

Data da Defesa: 07

Banca Examinadora

Prof. Dr.

Instituição: Julgamento:

Assinatura:

Prof. Dr.

Instituição: Julgamento:

Assinatura:

Prof. Dr.

Instituição: Julgamento:

Assinatura: 
A Deus, em primeiro lugar, por estar sempre me dando força, fé e perseverança para ultrapassar todos os obstáculos da minha vida.

Aos meus pais, Roberto (in memorian) e Marilena, por sempre me estimularem e estarem sempre ao meu lado, por acreditarem em mim, apesar dos meus erros; pelo amor, carinho e dedicação.

Aos meus irmãos, Fabiana e Ricardo, pela amizade, carinho, compreensão $e$ apoio.

Aos meus familiares pelo incentivo e carinho durante a realização deste trabalho. 
AGRADECIMENTO ESPECIAL 
À minha orientadora, Profa. Dra. Helena de Freitas Oliveira Paranhos, pela confiança depositada em meu trabalho. 
AGRADECIMENTOS 
A Prof. Dra. Cláudia Helena Lovato da Silva, pela amizade e acolhida em todos os momentos que precisei para concretização deste trabalho, e também pela colaboração profissional durante todo o projeto.

Ao Prof. Dr. Osvaldo Luiz Bezzon pelo incentivo ao longo da realização deste trabalho.

A minha grande amiga e colega no curso de pós-graduação, Ingrid, pela colaboração prestada para realização deste trabalho e apoio nos momentos de dificuldade.

A todos os meus amigos e familiares, que sempre me incentivaram a seguir meus objetivos.

A todos os professores, funcionários e colegas do Departamento de Materiais Dentários e Prótese da FORP-USP e do Curso de Pós-Graduação da FORP-USP.

Aos pacientes, sem os quais não seria possível a realização deste trabalho. 
SUMÁRIO 


\section{SUMÁRIO}

\section{RESUMO}

\section{ABSTRACT}

1.INTRODUÇÃO

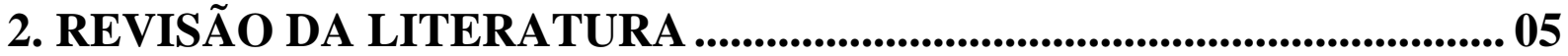

2.1. Métodos de higienização de próteses totais ......................................... 06

2.1.1. Agentes químicos......................................................................... 06

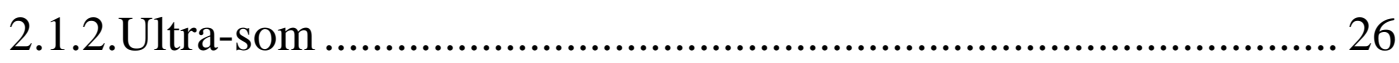

3. PROPOSIÇÃO ...................................................................................... 32

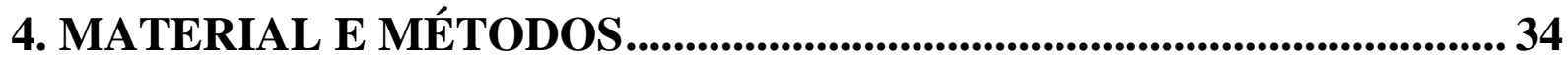

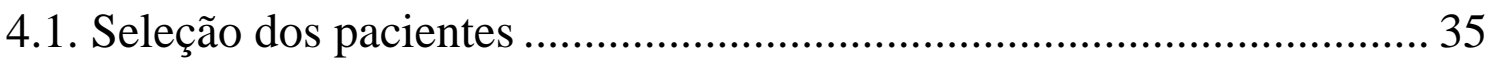

4.2. Métodos de higiene e delineamento experimental ................................ 36

4.3. Avaliação da capacidade de remoção do biofilme ............................... 39

4.3.1. Evidenciação do Biofilme e Fotografia das Próteses ................. 39

4.3.2. Quantificação do Biofilme........................................................... 40

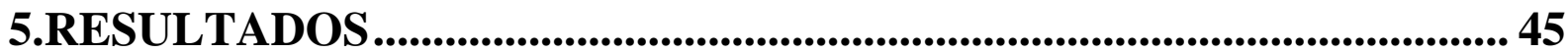

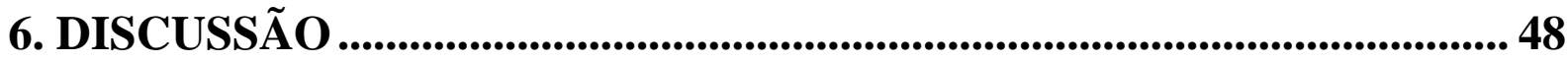

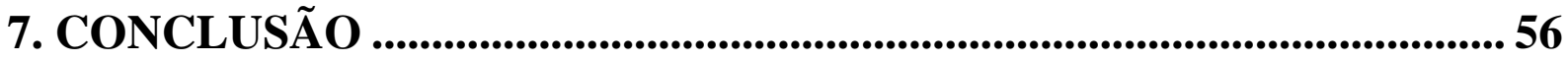

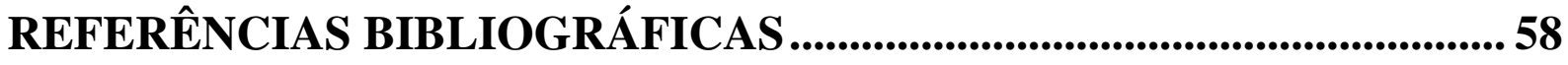

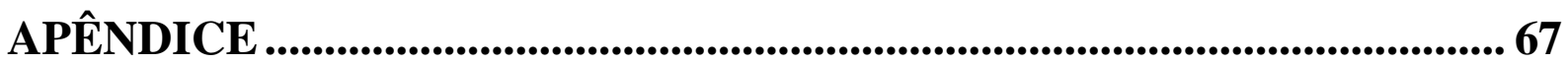

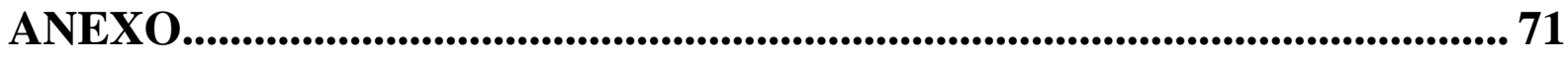




\section{RESUMO}

CRUZ, P.C. Avaliação clínica da efetividade dos métodos químico (peróxido alcalino) e mecânico (ultra-som) frente à propriedade de remoção de biofilme de próteses totais. 2007. 72 p. Dissertação (Mestrado) - Faculdade de Odontologia de Ribeirão Preto, Universidade de São Paulo, Ribeirão Preto, 2007.

O objetivo deste trabalho foi avaliar clinicamente a capacidade de remoção do biofilme da prótese total dos métodos de higiene: químico (pastilha efervescente para imersão de próteses totais à base de peróxido alcalino), mecânico (aparelho ultra-sônico), e associado (pastilha efervescente + aparelho ultra-sônico). Oitenta pacientes (usuários de próteses totais superiores e inferiores) participaram de um período experimental de 21 dias e foram distribuídos em 4 grupos ( $n=20)$ : 1) Controle - escovação das próteses com escova específica (Bitufo) 3 vezes ao dia (após café da manhã, almoço e jantar) com água; 2) Químico escovação das próteses com escova específica (Bitufo) 3 vezes ao dia (após café da manhã, almoço e jantar) com água e imersão em recipiente contendo $1 \frac{1}{2}$ copo de água morna e 01 pastilha efervescente Corega Tabs por 5 minutos; 3) Mecânico - escovação das próteses com escova específica (Bitufo) 3 vezes ao dia (após café da manhã, almoço e jantar) com água, e uma única agitação ultra-sônica por 15 minutos ao final do período experimental (21 dias); 4) Associado - associação dos métodos 2 e 3. Para a quantificação do biofilme, as superfícies internas das próteses totais superiores foram evidenciadas (vermelho neutro 1\%), fotografadas em $45^{\circ}$ (Canon EOS Digital Rebel), processadas (Adobe Photoshop 5.0) e as áreas (total da superfície interna e corada com biofilme) quantificadas (Image Tool 2.02). A porcentagem do biofilme foi calculada como a relação entre a área do biofilme multiplicado por 100 e a área da superfície total da base interna da prótese. Os resultados mostraram diferenças entre os métodos (teste de Kruskal-Wallis, significância de 0,05), com superioridade dos métodos químico (37.2), mecânico (35.2) e associado (29.1) sobre o controle (60.5). Como conclusão, a imersão em peróxido alcalino e o uso do ultra-som podem ser empregados como agentes auxiliares na higienização de próteses totais.

Palavras chaves: prótese total, biofilme, higienizadores de próteses totais. 
ABSTRACT 


\begin{abstract}
CRUZ, P.C. Clinical evaluation of the efficacy on biofilm removal from complete denture of the chemical (alkaline peroxide) and mecanical (ultrasonic) methods. 2007. 72 p. Dissertação (Mestrado) - Faculdade de Odontologia de Ribeirão Preto, Universidade de São Paulo, Ribeirão Preto, 2007.
\end{abstract}

The aim of this study was to evaluate the hability of the biofilm removal from complete denture of the chemical (alkaline peroxide-effervescent tablets to complete denture immersion), mechanical (ultrasonic) and combined (association of the effervescent and ultrasonical methods) methods. Eighty patients that use upper and lower complete denture participated of the experimental period of 21 days and they were distibuted in 4 groups ( $n=20): 1$ ) Control - brushing the dentures with especifc brush (Bitufo), 3 times a day (after breakfast, lunch and dinner) with water; 2) Chemical - brushing the dentures with especifc brush (Bitufo), 3 times per day (after breakfast, lunch and dinner) with water and immersion in a recipient containing warm water and 01 effervescent tablet of Corega Tabs for 5 minutes; 3) Mechanical - brushing the dentures with especific brush (Bitufo), 3 times a day (after breakfast, lunch and dinner) with water and only one ultrasonic vibration per 15 minutes in the end of the esperimental period (21 days); 4) Combined - association of the methods 2 and 3. To quantify the biofilm, the internal surfaces of the upper complete dentures were stained and photographed in $45^{\circ}$ (Canon EOS Digital Rebel), processed (Adobe Photoshop 5.0) and the areas (total internal surface and stained with biofilm) quantified (Image Tool 2.02). The percentage of the biofilm was calculated by the relation between biofilm area multiplier by 100 and total area of the internal surface of the upper complete denture. The results showed diferences between the methods (teste de Kruskal-Wallis, significância de 0,05), with superiority of the chemical (37.2), mechanical (35.2) and combined (29.1) methods above control group (60.5). As conclusion, the immersion with alkaline peroxide and the use of ultrasonic vibration can be employed as auxiliary agents on the hygiene of complete dentures.

Key Words: complete denture, biofilm, denture cleansers. 
O biofilme da prótese total é definido como uma camada microbiana densa, sendo constituído por mais de $10^{11}$ microrganismos por grama em peso seco (NIKAWA et al. ${ }^{77}$, 1999). Trabalhos demonstram a relação entre biofilme, inflamação da mucosa e Candidíase Atrófica Crônica (AKPAN; MORGAN ${ }^{8}$, 2002) e apontam a colonização da superfície interna de próteses totais como fonte de infecções $\left(\mathrm{GREEN}^{46}\right.$, 1979; MARTIN et al. ${ }^{62}$, 1994; NIKAWA et al. $\left.{ }^{77}, 1999\right)$.

A saúde oral de usuários de próteses totais é precária (BUDTZ-JØRGENSEN et al. ${ }^{28}$, 2000; MOSKONA; KAPLAN ${ }^{68}$, 1992; HOAD-REDDICK; GRANT; GRIFFITHS ${ }^{49}$, 1990; KULAK-OZKAN; KAZAZOLU; ARIKAN ${ }^{55}$, 2002; PARANHOS et al. ${ }^{80}$, 2000; SMITH; SHEIHAM $^{99}$, 1979). A má higiene está associada à falta de orientação, às características intrínsecas do aparelho e à diminuição da destreza manual dos pacientes (AMBJØRSEN; RISE $^{11}$, 1985; DILLS et al. ${ }^{40}, 1988 ;$ MURTOMAA; MEURMAN ${ }^{73}, 1992$; WENDT $^{105}$, 1985).

O produto ideal de higiene deve ser de fácil manuseio; efetivo na remoção dos depósitos orgânicos, inorgânicos e manchas; bactericida e fungicida; não tóxico ao paciente; não deletério aos materiais constituintes do aparelho e de baixo custo. Os métodos propostos podem ser divididos em mecânicos ou químicos (ABELSON ${ }^{1}, 1981$; ABELSON ${ }^{2}, 1985$; ABERE², 1979; BUDTZ-JØRGENSEN ${ }^{25}$, 1979; COUNCIL ON DENTAL MATERIALS, EQUIPMENTS AND INSTRUMENTS ${ }^{33}$, 1983; FERRAN et al. ${ }^{43}$, 1984; JAGGER; HARRISON $^{51}$, 1995). Os mecânicos são classificados em escovação (com água, sabão, pastas ou abrasivos) e aparelhos ultra-sônicos. Os químicos, de acordo com seus componentes principais e mecanismos de ação, são classificados em hipocloritos, peróxidos, peróxidos neutros com enzimas, enzimas, ácidos, drogas brutas e enxaguatórios para dentaduras (NIKAWA et al. $\left.{ }^{77}, 1999\right)$.

A escovação tem a vantagem de ser um método simples, de baixo custo e efetivo na remoção de manchas e depósitos orgânicos (BUDTZ-JØRGENSEN ${ }^{25}$, 1979; PURNAVEJA et 
al. $^{85}$, 1982); porém oferece dificuldades para pacientes com incoordenação motora $\left(\right.$ ABELSON $^{2}$, 1985; JAGGER; HARRISON ${ }^{51}$, 1995), além de existir a possibilidade do desgaste da resina acrílica e danos superficiais a materiais reembasadores (HASELDEN et al. ${ }^{48}$, 1998). É essencial o uso de escovas e agentes auxiliares adequados, pois pode haver alteração da superfície da resina acrílica, deixando-a rugosa e, conseqüentemente, mais propensa à retenção de biofilme $\left(\mathrm{ABERE}^{3}, 1979\right.$; DYER et al. ${ }^{41}, 2001$; PURNAVEJA et al. ${ }^{85}$, 1982; SATOH et al. ${ }^{90}$, 1990).

A higienização por agentes químicos consiste na imersão do aparelho em soluções com ação solvente, detergente, bactericida e fungicida (COUNCIL ON DENTAL MATERIALS AND EQUIPMENTS ${ }^{33}$, 1983). Tal método de limpeza, no qual estão inseridos, principalmente, os peróxidos e hipocloritos alcalinos, é tido como vantajoso, pelo fato de englobar todas as áreas da prótese total e não causar danos ao aparelho protético, no que se refere à abrasão (BUDTZ-JØRGENSEN ${ }^{25}$, 1979). Sendo um procedimento simples, é facilmente executado por pessoas debilitadas ou que perderam a coordenação motora e que não podem se adaptar à escovação. Porém, como desvantagens principais, podem ser citadas o clareamento da resina acrílica, a corrosão de componentes metálicos e o alto custo dos produtos no mercado (ABELSON ${ }^{2}$, 1985; JAGGER; HARRISON ${ }^{51}$, 1995).

Tais soluções podem ser utilizadas isoladamente ou combinadas com a escovação, sendo esta última opção rotineiramente recomendada (AUGSBURGER; ELAHI ${ }^{15}$, 1982; LEE et al. $^{57}$, 1985; HUTCHINS; PARKER ${ }^{50}$, 1973; KENG; LIM $^{53}$, 1996; NIKAWA et al. ${ }^{77}, 1999$; PARANHOS et al. $^{82}$, 2007a). Porém, experimentos mostram resultados contraditórios em relação à efetividade desses métodos, sendo divulgado superioridade do método químico (CHAN et al. ${ }^{29}$, 1991; DILLS et al. $^{40}$, 1988; KULAK et al. $^{54}$, 1997), da escovação (MUHLER; STOOKEY; HASSELL ${ }^{71}$, 1969; TARBET et al. ${ }^{100}$, 1984) ou da associação de ambos os métodos (BASSON; QUICK; THOMAS ${ }^{18}$, 1992; COBARGAS; CRUZAT; 
MIERZO $^{31}$, 2001; CHAN et al. ${ }^{29}, 1991$; LEE et al. ${ }^{57}$, 1985; PARANHOS et al. ${ }^{82}, 2007$ a; SESMA et al. ${ }^{91}$, 1999).

O ultra-som consiste em método mecânico alternativo, geralmente de uso profissional, que inclui sistemas de vibradores sônicos e ultra-sônicos. A ação de limpeza mecânica do aparelho é complementada pelo agente de imersão (SHAY $\left.{ }^{94}, 2000\right)$. A associação do ultrasom à escovação ou a um método químico tem sido sugerida como alternativa efetiva para limpeza de próteses totais (GWINNETT; CAPUTO ${ }^{47}$, 1983; SHAY $^{94}$, 2000), porém, tal efetividade não tem sido clinicamente testada.

A literatura evidencia a necessidade do controle do biofilme, com a instituição de métodos adequados, efetivos e que não causem danos aos materiais constituintes do aparelho. Mostra também a necessidade de testes clínicos e laboratoriais desses produtos. Sendo assim, o objetivo deste trabalho será avaliar clinicamente a capacidade de remoção do biofilme de um método químico (peróxido alcalino) e um mecânico (ultra-som), bem como a associação de ambos, visando, dessa forma, contribuir com a manutenção da saúde oral dos usuários de próteses totais. 


\section{REVISÃO DA LITERATURA}




\subsection{MÉTODOS DE HIGIENIZAÇÃO DE PRÓTESES TOTAIS}

\subsubsection{AGENTES QUÍMICOS}

Os principais higienizadores químicos comercialmente disponíveis são classificados como soluções de peróxidos e hipocloritos alcalinos. Os peróxidos alcalinos são combinações químicas complexas de ingredientes ativos designados para agir sobre os constituintes orgânicos dos depósitos das dentaduras.

Os ingredientes específicos e concentrações dos peróxidos variam; porém, as soluções comerciais incluem componentes oxidantes (frequentemente o perborato alcalino), efervescentes (perborato e/ou carbonato), redutores de tensão superficial (detergentes) e agentes quelantes (EDTA) (ABELSON², 1985).

As próteses totais são imersas nestas soluções, sendo o período de imersão indicado pelos fabricantes. Quando dissolvidos em água, tornam-se soluções alcalinas de peróxidos de hidrogênio que, em contato com a matriz orgânica do biofilme, ou seja, restos alimentares e mucinas, decompõem-se originando pequenas e múltiplas bolhas de gás oxigênio. Estas bolhas, sob condições adequadas, exercem uma ação de desprendimento mecânico (limpeza mecânica) entre a superfície protética e o biofilme. Sendo assim, tais soluções promovem a desagregação, dissolução e remoção de tais depósitos, sendo que tal ação é realizada por meio de propriedades alcalinas e efervescentes do produto higienizador. O processo de catalisação de $\mathrm{H}_{2} \mathrm{O}_{2}$ para $\mathrm{O}_{2}$ varia com o produto higienizador e a diferenciação dos higienizadores pode ser feita em termos de concentração de $\mathrm{Cl}^{-}$(MUELLER; GREENER ${ }^{69}$, 1980). A ação higienizadora depende parcialmente da liberação de bolhas de oxigênio pela solução em contato com a matriz orgânica, do efeito solubilizante do fosfato alcalino e da ação detergente. 
São menos efetivos sobre cálculos ou manchas pesadas, sendo mais efetivos quando usados regularmente em depósitos leves (ABELSON ${ }^{1}, 1981 ; \mathrm{ABERE}^{3}, 1979$; $\mathrm{LANGWELL}^{56}$, 1955; MacCALLUM; STAFFORD; MacCULLOCH ${ }^{65}$, 1968; NEILL ${ }^{75}, 1968$; THEILADE $^{102}$, 1958). Devido a isso, seu uso principal está indicado em próteses totais que são higienizadas frequentemente e que não acumularam depósitos pesados e firmemente aderidos. Podem ser utilizados isoladamente ou associados com um método mecânico, como a escovação, ou o ultra-som (método combinado).

Sua efetividade também está relacionada com o período de imersão, sendo mais efetivos quando usados por períodos prolongados (soluções “overnight”) (ANTHONY; GIBBONS $^{13}$, 1958; BECK ${ }^{20}$, 1973; BUDTZ-JØRGENSEN ${ }^{21}$, 1977; BUDTZ-JØRGENSEN; KELSTRUP ${ }^{22}$, 1977; HUTCHINS; PARKER ${ }^{50}$, 1973; NICHOLSON; STARK; SCOTT ${ }^{76}$, 1968). A temperatura da água também deve ser observada, sendo relatada uma temperatura de $50^{\circ} \mathrm{C}$ como ideal (McCABE et al. $\left.{ }^{63}, 1995\right)$.

Têm odor agradável e as apresentações comerciais tomam várias formas, entre as mais populares, estão aquelas distribuídas como tabletes ou pós. São de manipulação segura, pois não têm a alta acidez dos ácidos e nem a alta alcalinidade dos hipocloritos alcalinos, mostrando poucos danos aos componentes metálicos de aparelhos protéticos (LANGWELL ${ }^{56}$, 1955; MacCALLUM; STAFFORD; MacCULLOCH ${ }^{65}$, 1968; NEILL ${ }^{75}, 1968 ;$ SMITH $^{98}$, 1966). A maioria das formulações mais novas são menos alcalinas e estão essencialmente na faixa neutra.

Devido à sua composição química, são menos estáveis que as soluções de hipocloritos alcalinos e devem ser protegidos da atmosfera para não perderem seus ingredientes ativos. Alguns higienizadores são embalados individualmente que, de acordo com os fabricantes, oferecem proteção ao produto e promovem estabilidade física e química, promovendo uma vida útil de aproximadamente 3 anos. 
Tais soluções podem não ser compatíveis com alguns forradores resilientes temporários ou permanentes, devendo o paciente ter o cuidado de minimizar o período de imersão quando esses materiais estiverem presentes (BATES; SMITH ${ }^{19}$, 1965; DAVENPORT et al. $^{38}$, 1996; NEILL ${ }^{75}$, 1968; SMITH $^{98}$, 1966). Também, como efeito adverso, tem sido apontado a possibilidade de clareamento da resina acrílica (ABELSON ${ }^{2}$, 1985; BUDTZ-JØRGENSEN ${ }^{25}$, 1979; COUNCIL ON DENTAL MATERIALS AND EQUIPMENTS $^{33}$, 1983; JAGGER; HARRISON ${ }^{51}$, 1995; ROBINSON; McCABE; STORER $^{87}$, 1985). Porém, existem controvérsias em relação às causas do clareamento, sendo a temperatura da água utilizada, um fator crítico a ser observado (ARAB; NEWTON; LIOYD $^{14}$, 1988; CRAWFORD; NEWTON; YEMM ${ }^{34}$, 1985; CRAWFORD et al. ${ }^{35}$, 1986; CRAWFORD; NEWTON; YEMM ${ }^{36}$, 1987).

Ainda, em relação a efeitos colaterais, trabalhos em seres humanos e em cães, mostraram que, em contato com a mucosa, esses produtos, devido à sua constituição química, podem causar edema local, inflamação e descamação da mucosa (ABRAMSON et al. ${ }^{4}, 1974$; ABRAMSON et al. ${ }^{5}$, 1975; ABRAMSON ${ }^{6}$, 1978; BARCLAY; FINLAYSON ${ }^{17}, 1985$; MACKENZIE $\left.^{58}, 1982\right)$.

Trabalhos clínicos, objetivando uma comparação da efetividade de soluções de peróxidos alcalinos com pastas ou outras soluções químicas (hipocloritos alcalinos, enzimas, anti-sépticos ou anti-fúngicos) têm sido realizados e mostram resultados variados.

Neill $^{75}$ (1968) testou diversos higienizadores de próteses totais (estudo clínico e laboratorial) para avaliação da propriedade de remoção de biofilme e manchas. Na fase clínica, 11 higienizadores, do tipo imersão (peróxidos) e escovação com pastas ou pós abrasivos (Dento, Dentifresh, Sanident, Librox, Eucryl, Steradent, Wernets, Dentural, Oxydent, Kolynos e Lustredent) foram testados em 76 indivíduos durante um período experimental de 05 semanas. Na fase laboratorial, as próteses foram seccionadas em várias 
amostras e posteriormente submetidas aos procedimentos de higiene. Em ambas as situações (clínica e laboratorial) foram utilizadas fotografias das próteses e/ou amostras obtidas antes e após o uso dos produtos higienizadores. A imersão noturna em soluções alcalinas (peróxidos e hipocloritos) consistiu-se em método seguro e efetivo para controle do biofilme. Segundo o autor, a escovação deve ser realizada com cautela, utilizando produtos de baixa abrasividade.

Hutchins e Parker ${ }^{50}$ (1973) investigaram a capacidade de remoção de biofilme recémformado de 11 soluções higienizadoras (pó ou tablete). O estudo foi dividido em várias fases, e foram selecionados 07 usuários de próteses totais e/ou removíveis. Com o objetivo de eliminar o biofilme presente, os aparelhos foram evidenciados com solução de azul de metileno a 4\% (preparado em partes iguais de álcool e água) e escovados até sua total remoção. Em uma primeira fase, foram testadas as soluções em períodos diferentes de imersão (15 minutos e 6 horas). Em uma segunda fase, os pacientes fizeram uso caseiro das soluções (imersão noturna durante 07 dias). Na terceira fase, foi utilizada uma única solução à base de hipoclorito alcalino (Mersene) em dois períodos diferentes de imersão (15 minutos e 1 hora). Em cada fase, as próteses foram enxaguadas em água, fotografadas, coradas e fotografadas novamente para avaliação quanto à presença ou não de biofilme. Na quarta fase, com o objetivo de avaliar os efeitos adversos, próteses parciais removíveis confeccionadas com liga de cobalto-cromo foram imersas na solução de hipoclorito alcalino (Mersene) durante 2 meses, sendo esta solução trocada diariamente. Os resultados mostraram que o hipoclorito alcalino (Mersene) removeu efetivamente o biofilme sem danos à superfície do aparelho (períodos de 15 minutos ou 6 horas). Os autores chamam a atenção para o fato de que o biofilme maduro é mais difícil de ser removido do que o biofilme de 24 horas; por isso, as próteses devem ser inicialmente escovadas até a sua completa limpeza e posteriormente conduzidas a um processo de imersão regular durante a noite. É imprescindível orientar o paciente quanto à higiene oral e o controle deste processo por meio do uso de evidenciadores. 
Shannon, McCrary e Starcke ${ }^{92}$ (1976) testaram nove agentes higienizadores, sendo oito à base de peróxido alcalino: Denalan (pó), Denalan (tabletes), D. O. C., Efferdent, Kleenite, Ora, Polident (pó), Polident (tablete) e um à base de hipoclorito alcalino (Mersene). Amostras de resina acrílica foram imersas em saliva artificial, tratadas com as soluções de imersão (15 minutos ou 8 horas) e avaliadas quanto à propriedade de remoção do biofilme, por meio da atribuição de escores. O tratamento por 15 minutos indicou que houve apenas um efeito de clareamento e os depósitos permaneceram inalterados. O tratamento com 8 horas indicou que os tabletes de peróxidos alcalinos Efferdent e Polident (peróxidos alcalinos) foram mais efetivos que os outros produtos, embora $1 / 4$ a $1 / 3$ dos depósitos tenham permanecido na superfície da resina acrílica. Os autores salientaram a diversidade dos materiais disponíveis no mercado, sendo que os mesmos não são totalmente efetivos e chamam a atenção da necessidade do profissional explicar a natureza de cada produto ao paciente e educá-lo quanto ao uso de evidenciadores, de maneira que a escolha do material e método seja feita de modo individual e objetivo.

Connor, Schoenfeld e Taylor ${ }^{32}$ (1977) avaliaram clinicamente a eficácia de remoção de biofilme de uma solução experimental enzimática (Miles Laboratories, Inc.), comparando-a com um agente higienizador à base de peróxido alcalino (Efferdent - Warner Lambert). Tais soluções foram testadas em períodos de imersão de 15 minutos e 8 horas. Próteses totais superiores de 12 pacientes foram confeccionadas em duplicata e, em uma delas, inseridos três discos de ouro no flanco bucal esquerdo. Os pacientes foram instruídos a usar suas próteses continuamente durante 48 horas e após esse intervalo, os discos foram removidos e examinados em microscópio eletrônico de varredura. Em um período de 15 minutos de imersão, não houve diferença entre os produtos; porém, quando foi utilizado um período de 8 horas, o produto experimental mostrou-se mais eficaz. Os resultados mostraram que a incorporação de enzimas em um agente de higienização aumenta sua efetividade e o período 
de imersão também é importante, uma vez que 15 minutos não foram suficientes para a ação enzimática. Os autores salientaram que houve uma variação na espessura do biofilme, sendo esta determinada principalmente pelo número de microrganismos presentes e chamam a atenção da necessidade de pesquisas futuras para formulação de enzimas mais apropriadas para tal objetivo.

Para verificar a eficácia das enzimas, Budtz-Jørgensen ${ }^{21}$ (1977) testou tabletes contendo mutanase e protease na prevenção da formação de biofilme na superfície interna de próteses totais. Participaram do experimento 60 pacientes com Estomatite Protética, que foram orientados a imergir seus aparelhos recém-confeccionados 1 vez ao dia (15 minutos) pelo período de 1 mês em recipiente em água morna a $37^{\circ} \mathrm{C}$ nos agentes higienizadores: 1) Solução enzimática (0,2g de mutanase e 0,5g de protease) (A/S Novo), Steradent ( Reckitt and Colman Products Ltd.) ou Placebo. Os níveis de biofilme, as condições clínicas da mucosa palatina e a concentração de leveduras (mucosa e prótese) foram registrados durante o uso das dentaduras velhas e durante o período experimental (com dentaduras novas). O exame clínico foi realizado com auxílio de fotografias do palato e avaliando-se a proporção dos eritemas palatinos, antes e após a higiene preconizada. A avaliação da higiene foi feita com o emprego de um evidenciador de biofilme (proflavina monossulfato) e fotografia da superfície interna do aparelho. O grupo de pacientes que utilizou as enzimas registrou uma redução dos escores de biofilme, quando comparado com os escores das próteses originais, enquanto os outros 2 grupos (constituídos de imersão em Steradent ${ }^{\circledR}$ e placebo) não tiveram efeito aparente.

Budtz-Jørgensen e Kelstrup ${ }^{22}$ (1977) estudaram e eficácia das enzimas dextranase, mutanase e protease (puras ou misturadas) na remoção de biofilme de 100 usuários de próteses totais que apresentavam Estomatite Protética. O experimento constituiu de 2 partes: 1) Teste de 5 tipos de tabletes contendo: protease, mutanase, dextranase, uma mistura das três enzimas e placebo; e 2) Teste de 3 tipos de tabletes contendo: mistura de protease e mutanase, 
placebo e uma solução de imersão à base de peróxido alcalino (Steradent). Os produtos foram dissolvidos em $150 \mathrm{~mL}$ de água morna e utilizados duas vezes ao dia por 15 minutos. O período experimental foi de 14 dias. Foram avaliados, por meio de escalas de atribuição de escores, os níveis de biofilme, o grau de eritema e a ocorrência de células de Cândida e leucócitos (mucosa e prótese). Foi observado que a combinação de enzimas foi mais efetiva na remoção de biofilme, melhorando significativamente a saúde dos tecidos palatinos.

Budtz-Jørgensen ${ }^{23}$ (1978) testou a efetividade de tabletes contendo enzimas (mutanase e protease) em concentrações diluídas. Os exames foram realizados em 40 pacientes. O autor analisou a inflamação de mucosa, o acúmulo de biofilme na superfície interna da prótese e a ocorrência de células bacterianas e leveduras, por meio de esfregaços (mucosa e do aparelho protético) no início do experimento e após a imersão do aparelho por 2, 6 e 20 semanas. Os resultados mostraram uma diminuição do biofilme, hifas e bactérias, bem como uma melhora clínica da estomatite após 6 semanas de imersão diária. O autor chama a atenção que as enzimas não são terapia antimicrobiana ou substitutos da escovação, mas um produto adjunto eficaz no tratamento da Estomatite Protética e, em períodos longos de imersão, aumentam a capacidade de remoção do biofilme.

Budtz-Jørgensen e Knudsen ${ }^{24}$ (1978) avaliaram a eficácia dos métodos de escovação e imersão. Foram avaliadas próteses totais recém-confeccionadas e a mucosa palatina de 74 pacientes acometidos com Candidíase Atrófica Crônica, que foram distribuídos nos seguintes grupos: 1) Escovação com escova específica para dentaduras (Tandex) duas vezes ao dia com gel de clorexidina a 1\% (Hibitane); 2) Escovação com escova específica para dentaduras (Tandex) e gel placebo (ICI); 3) Método rotineiro de escovação associada à imersão em solução de peróxido alcalino (Steradent - Reckitt and Colman Products Ltd.) em 150mL de água morna $\left(37^{\circ} \mathrm{C}\right) 1$ vez ao dia por 15 minutos; 4) Método rotineiro de escovação associada à imersão em solução placebo em $150 \mathrm{~mL}$ de água morna $\left(37^{\circ} \mathrm{C}\right) 1$ vez ao dia por quinze 
minutos. O período experimental empregado foi de 1 mês. Os pacientes foram avaliados antes e após o tratamento, por meio de escalas de atribuição de escores, quanto aos níveis de biofilme, grau de eritema da mucosa palatina e concentração de leveduras (mucosa e superfície interna das próteses totais superiores). Os resultados mostraram que houve formação de biofilme em todas as próteses, porém, em grau menor para os géis de clorexidina e placebo. Tanto a clorexidina, como a solução de imersão (Steradent) não mostraram ação antimicrobiana (mucosa e prótese). Apesar de pequena melhora com o uso do gel de clorexidina, não houve diferença entre os produtos quanto ao grau de eritema da mucosa palatina. Não houve correlação entre o grau de eritema e os níveis de biofilme. Os resultados sugerem que a escovação meticulosa da prótese é relativamente efetiva no controle do biofilme e que a solução química de imersão não teve efeito aparente.

Manderson e Brown ${ }^{59}$ (1978), em experimento laboratorial e clínico, compararam dois produtos de higiene, um a base de ácido sulfâmico (Valdent - Reckitt and Colman Products Ltd.) e outro à base de perborato alcalino (Steradent - Reckitt and Colman Products Ltd.). Foi avaliado, no estudo laboratorial, o efeito dos produtos sobre as propriedades dos materiais constituintes das próteses (resina da base, dentes artificiais, metais e forradores resilientes). No estudo clínico foram avaliadas a habilidade de remoção de biofilme e a atividade antifúngica. Para a avaliação clínica foram selecionados 6 pacientes, que foram instruídos a imergir suas próteses em recipiente com $150 \mathrm{~mL}$ de água corrente a $55^{\circ} \mathrm{C}$. As próteses foram fotografadas sob condições padronizadas de luz, antes e após os procedimentos de limpeza. Para a quantificação de biofilme, foi empregada escala de escores. Os resultados das análises (laboratorial e clínica) mostraram efetividade do produto à base de ácido sulfâmico, sem danos aparentes aos materiais constituintes das próteses.

Rustogi et al. ${ }^{88}$ (1979) compararam a eficácia de 4 produtos higienizadores comercialmente disponíveis na remoção diária do acúmulo de biofilme em próteses totais. 
Foram selecionados 15 pacientes. Os produtos testados foram do tipo efervescente, dois produzindo dióxido de carbono: tabletes de Efferdent e Polident (peróxidos alcalinos) e dois produzindo oxigênio: Polident em pó (peróxido alcalino) e Mersene em grãos (hipoclorito alcalino). Os períodos de imersão foram 15 minutos e 9 horas (“overnight”). O grupo controle foi constituído de imersão em água. O paciente foi instruído a não higienizar as próteses por 23 horas antes do experimento. Após o uso dos produtos, as próteses foram imersas em eritrosina a $1 \%$ por 2 minutos e enxaguadas. Em seguida, a eritrosina remanescente no biofilme foi coletada e o biofilme foi quantificado utilizando um método semi-quantitativo. Dos agentes testados, o Mersene foi o mais efetivo, enquanto os tabletes de Polident e Efferdent mostraram-se significativamente menos eficazes, mesmo em imersão prolongada (9 horas).

Walker et al. ${ }^{104}$ (1981) testaram o efeito de um antimicótico (Anfotericina) e de um peróxido alcalino (Steradent - Reckitt and Colam Products Ltd.) no tratamento da Candidíase Atrófica Crônica em 49 pacientes por um período de 5 semanas. Foram realizados esfregaços da superfície interna da prótese total superior e da mucosa palatina. A C. albicans foi identificada por métodos padronizados e as alterações inflamatórias da mucosa foram graduadas numa escala de 0 a 3, de acordo com a densidade dos leucócitos presentes nos esfregaços epiteliais. Os resultados mostraram que nenhum dos agentes foi efetivo na redução de Candida, da inflamação da mucosa ou da prevenção do acúmulo de biofilme. Segundo os autores, a estomatite de dentadura só pode ser efetivamente tratada por meio da remoção mecânica do biofilme.

Augsburger e Elahi ${ }^{15}$ (1982) estudaram as propriedades de limpeza de higienizadores químicos de imersão de próteses totais em um grupo de 110 pacientes. Os produtos empregados foram 4 peróxidos alcalinos: Denalan (Whiteball Laboratories Inc.), Efferdent (Warner-Lambert Co.), Polident (Block Drug Co.) e Kleenite (Vick Chemical Co.) e 01 
hipoclorito alcalino (Mersene - Colgate-Palmolive Co.). As próteses totais foram evidenciadas e examinadas quanto à presença de biofilme e manchas por meio de escala de atribuição de escores. Os resultados mostraram que a efetividade em relação à remoção de manchas variou de 26 a 57\% e em relação à remoção de biofilme de 6 a 42\%. Diferenças significativas foram encontradas entre os níveis de biofilme quando comparadas às superfícies externas e internas dos aparelhos protéticos. Os autores concluíram que as superfícies convexas e lisas acumularam menos biofilme que aquelas superfícies com esculturas mais proeminentes. O período de imersão utilizado (10 minutos) não foi satisfatório para a limpeza, sendo necessária a preconização de períodos mais longos, associados à escovação mecânica. O Mersene (hipoclorito alcalino) e o Kleenite (peróxido alcalino) foram os mais efetivos, tanto para a remoção de manchas, como para remoção de biofilme.

Ghalichebaf, Graser e Zander ${ }^{44}$ (1982) compararam a efetividade de 4 higienizadores de próteses totais do tipo imersão, sendo 02 à base de hipoclorito alcalino, Mersene (ColgatePalmolive Co.) e Clorox-Calgon (The Clorox Co.; Beecham Products) e 02 à base de peróxido alcalino, Efferdent (Warner-Lambert Co.) e Polident (Block Drug Co.) utilizando metodologia quantitativa para análise dos níveis de biofilme. Foram selecionados 15 pacientes usuários de próteses totais. Uma cavidade $(1 \mathrm{X} 1 \mathrm{~cm})$ foi confeccionada na região da tuberosidade de cada prótese total superior, sendo posteriormente moldada para confecção de enxertos de resina acrílica. Os enxertos foram esterilizados (autoclave) e inseridos na região preparada. Após o uso das próteses por 24 horas, foram removidos, corados com eritrosina (5\%) e fotografados sob condições padronizadas. Os diapositivos obtidos foram projetados em anteparo quadriculado para o cálculo da porcentagem da superfície corada. O número de áreas evidenciadas em relação à área total forneceu a porcentagem da superfície corada pelo biofilme. Os resultados mostraram eficácia do Mersene e do Clorox-Calgon, demonstrando que a capacidade de limpeza estava relacionada com a alcalinidade. 
Budtz-Jørgensen, Kelstrup e Poulsen ${ }^{26}$ (1983) examinaram a eficácia de uma preparação de protease (Alcalase ${ }^{\circledR}$ ) na prevenção do acúmulo de biofilme na superfície interna de próteses totais superiores de 17 pacientes. Tabletes de enzimas em diferentes concentrações e tabletes placebo foram utilizados uma vez ao dia por 15 minutos acompanhados ou não de escovação. As análises estatísticas mostraram que houve uma redução significante dos escores de biofilme com o aumento da concentração da enzima. A redução mais efetiva foi encontrada quando a higienização mecânica foi combinada com a imersão em solução de 500 mg de enzima. Em uma concentração de 300 mg ou mais, a imersão foi tão eficiente quanto a limpeza mecânica.

DePaola et al. $^{39}$ (1984) testaram a atividade antimicrobiana de 14 produtos (higienizadores de dentaduras, antissépticos orais e desinfetantes) disponíveis no mercado: Kleenite (Vicks Toiletry Products Div.), Efferdent (Warner-Lambert Co.), Polident (Block Drug Co.), Mersene (Colgate-Palmolive Co.), Gluconato de clorexidina a $1 \%$ (Stuart Pharmaceuticals), Clorasséptico (Norwich-Eaton Pharmaceuticals), Listerina (WarnerLambert Co.), Greene Mint (Block Drug Co.), Signal (Lever Brothers), Scope (Proctor and Gamble Co.), Lavoris (Block Drug Co.), Cepacol (Merril National Laboratories), Betadine Mouthrinse Gargle (The Purdue Frederick Company) contra microrganismos patogênicos ( $P$. aeruginosa, Kleibiela pneumoniae, Enterobacter cloacae, E. coli, E. aureus, C. albicans e T. glabrata) em 16 pacientes cancerígenos imunodeprimidos. Dos agentes higienizadores, o Kleenite (Vick Chemical Co.) foi o que apresentou a maior inibição microbiana, sendo seguido pelo Efferdent (Warner-Lambert Co.) e o Polident (Block Drug Co.). Dos agentes antissépticos, o gluconato de clorexidina apresentou os melhores resultados, vindo em $2^{\circ}$ lugar o Listerine e o Clorasséptico. Os melhores agentes com atividade inibitória e bactericida foram o Kleenite, Efferdent, Polident, Listerine, Clorasséptico e Gluconato de Clorexidina a 1\%, pois inibiram todos os microrganismos numa diluição 1:4. Os autores chamam a atenção 
para o fato de que o uso desses agentes pode prevenir a contaminação da cavidade oral por microbiota proveniente da dentadura, a qual tem o potencial de colonizar e infectar pacientes cancerígenos.

Budtz-Jørgensen e Attström ${ }^{27}$ (1984) avaliaram a efetividade de uma solução antibacteriana (Octapinol - Ferrosan), frente ao controle do biofilme de próteses totais. Foram selecionados 40 pacientes, que foram distribuídos em dois grupos: 1) Com Candidíase Atrófica Crônica, os quais foram instruídos a imergir suas próteses por 15 minutos na solução higienizadora (Octapinol a 1\%), duas vezes ao dia; 2) Com mucosa normal, os quais foram instruídos a imergir suas próteses por 15 minutos na solução higienizadora (Octapinol a 1\%), duas vezes ao dia, e realização de escovação após a imersão. O período experimental foi de 14 dias. A solução controle utilizada foi solução salina. Os autores avaliaram, por meio de escalas de atribuição de escores, os níveis de biofilme, o grau de eritema e a ocorrência de células fúngicas. Os resultados mostraram que houve redução dos níveis de biofilme, mostrando que é possível controlar a ocorrência de Candidíase com a utilização de uma substância com baixa atividade antibacteriana; porém, o risco de aparecimento de manchas deve ser considerado, limitando o seu uso rotineiro em programas de higiene.

Moore, Smith e Kenny ${ }^{67}$ (1984) compararam a eficácia de 8 produtos de limpeza de próteses totais na remoção ou eliminação de microrganismos aeróbicos, anaeróbicos e leveduras. Foram realizados testes clínicos e laboratoriais. Nos quais foram testados peróxidos alcalinos Denalan (Whiteball Laboratories Inc.), Efferdent (Warner-Lambert Co.), Kleenite (Vick Chemical Co.), Polident (Block Drug Co.), hipocloritos alcalinos Mersene (ColgatePalmolive Co.), Clorox-Calgon (The Clorox Co.; Reecham Products), um produto de origem desconhecida (Miller's) e escovação com água e sabão. Os resultados mostraram que o Miller's e Kleenite foram os agentes sanitizantes mais efetivos. Em segundo lugar, veio a escovação com água e sabão combinada com a imersão no agente Mersene. Embora o Clorox- 
Calgon tenha se mostrado efetivo na eliminação de leveduras em condições laboratoriais, ele não foi efetivo em condições clínicas. Os outros três agentes (Denalan, Efferdent e Polident) não foram efetivos. Os autores salientaram que a função de um higienizador de dentadura deve ser a remoção dos depósitos e manchas, bem como sanitização do aparelho protético.

Tarbet et al. ${ }^{100}$ (1984) comparam a habilidade de limpeza de dois métodos de higienização, imersão em Efferdent (Warner-Lambert Co.) e Polident (Block Drug Co.) e escovação com pasta de baixa abrasividade (Complete - Richardson-Vicks Inc.) em 75 desdentados totais. As próteses totais superiores foram evidenciadas com eritrosina (F.D. \& C., Red $n^{\circ}$ 3) e as superfícies interna e externa (flancos bucais direito e esquerdo) avaliadas de acordo com escala de escores. Os pacientes foram instruídos a utilizar os produtos durante 12 semanas consecutivas, de acordo com as instruções do fabricante. Os resultados demonstraram a efetividade do uso isolado da escovação com a pasta.

Lee et al. ${ }^{57}$ (1985) chamam a atenção que vários métodos de limpeza de próteses totais têm sido avaliados quanto à sua eficácia e nenhum foi aceito, ainda, como o melhor. Os autores avaliaram métodos populares de limpeza e tentaram desenvolver uma maneira simples de higienização. Pelos resultados obtidos, o método combinado (escovação e higienizador do tipo imersão) foi o método mais efetivo de limpeza, sendo que a escovação deve ser precedida pela imersão. O Estreptococos foi o microrganismo mais comum no biofilme da dentadura e não houve diferença quanto aos microrganismos quando as dentaduras superiores e inferiores foram comparadas.

Minagi et al. ${ }^{66}$ (1987) compararam a eficácia de agentes higienizadores à base de enzimas com um à base de peróxido alcalino. Foram utilizadas duas próteses totais superiores e uma inferior, de maneira que as mesmas foram seccionadas em vários fragmentos de aproximadamente $5 \mathrm{~mm}$ e distribuídos em 4 grupos: controle, dois agentes higienizadores com enzimas: Pika (enzima proteinase e glucanase - Rohto Pharmaceutical Co.) e Polident 
(Block Drug Co.) e um agente higienizador à base de peróxido alcalino (Efferdent - Warner Lambert Co.). Os autores avaliaram a atividade anti-fúngica e a porcentagem do acúmulo de biofilme de cada amostra, utilizando análises gráficas computadorizadas. Os resultados mostraram uma superioridade, no que se refere ao efeito de limpeza, dos dois produtos à base de enzima. Quanto à atividade anti-fúngica, os melhores resultados foram obtidos com um dos produtos à base de enzimas (Pika).

Dills et al. ${ }^{40}$ (1988) compararam, por meio de dois experimentos clínicos, a atividade antimicrobiana de dois métodos populares de higiene de próteses totais: escovação e imersão. No primeiro experimento, foram comparados 4 tratamentos: escovação com escova (CurvClean Denture Brush) e pasta específica à base de carbonato de cálcio (Dentu-Cream) por 30 segundos; imersão em solução de peróxido alcalino (Efferdent-Warner Lambert Co.) por 12 minutos em água a $45^{\circ} \mathrm{C}$; escovação com pasta de formulação experimental para dentadura seguida de imersão em Efferdent; sem tratamento. No segundo experimento: escovação com pasta de formulação experimental para dentadura; imersão em solução de peróxido alcalino (Efferdent) por 12 minutos em água a $45^{\circ} \mathrm{C}$; escovação com pasta específica (Dentu-Cream) e imersão em Efferdent; sem tratamento. O período de acúmulo de biofilme foi de 48 ou 72 horas, sendo que, neste período, foi suspenso qualquer tipo de procedimento de limpeza. Foram realizados esfregaços das superfícies internas das próteses e realizadas semeaduras em meios não seletivos e seletivos para Fusobacterium sp, rods gram - anaeróbicas (Fusobacterium sp); coco facultativo gram + (estreptococos) e coco anaeróbico gram (Veillonella sp) Os resultados mostraram uma superioridade da solução química, mesmo quando comparada com o método combinado (escovação e imersão). Estes resultados sustentam a necessidade do uso de um agente higienizador químico em adição à escovação com uma pasta adequada para dentadura para que bons resultados sejam alcançados. 
Chan et al. ${ }^{29}$ (1991) compararam a eficácia de uma solução para imersão (Efferdent Extra-Strength Denture Cleanser Tablets) e uma pasta para prótese (Advanced Formula Dentu-Creme Denture Cleaning Paste), mesmos produtos testados por Dills et al. (1988), porém em formulações canadenses, na remoção e eliminação de bactérias do biofilme de próteses removíveis. O estudo foi conduzido com 18 indivíduos que foram distribuídos aleatoriamente em 4 tratamentos: 1) controle; 2) escovação com pasta para prótese; 3) imersão em Efferdent; 4) escovação seguida de imersão em Efferdent. Colheitas microbiológicas foram realizadas antes e após cada tratamento. Os resultados mostraram que os métodos químicos e mecânicos foram igualmente efetivos. A escovação isolada apresentou piores resultados, quando comparada com o higienizador de imersão, tendo resultado somente sobre fusobactérias. O método combinado foi mais efetivo em maior número de microrganismos (facultativas totais e bactérias anaeróbias). Unindo este achado à falta de destreza manual de muitos idosos, a pasta abrasiva não deve ser recomendada como método isolado para a manutenção de uma boa higiene da prótese. O tratamento combinado remove resíduos alimentares, bem como outros materiais indesejados, sendo o método preconizado pelos autores.

Temer et al. ${ }^{101}$ (1991) avaliaram a eficácia do Corega Extradent em relação à aderência de fungos em bases de próteses. Os resultados mostraram que a higiene da prótese está relacionada à inflamação da mucosa palatina. O número de fungos foi determinado antes e após 2 dias de tratamento com o produto, sem alteração dos hábitos de higienização e uso das próteses pelos pacientes. O número de fungos diminuiu em todos pacientes examinados, porém em próteses com grande número de fungos e com higiene extremamente deficiente, o efeito do produto foi menor, indicando a necessidade de higienização mecânica adicional com uma escova. 
Ödman ${ }^{78}$ (1992) estudou a efetividade de um produto contendo protease (Enzydent $\left.{ }^{\circledR}\right)$ por meio de métodos microbiológicos (contagem de ufc). Durante um período de 3 semanas, 13 pacientes usaram somente o produto-teste, e durante as 3 semanas subseqüentes usaram o produto, e posteriormente a escovação. Os resultados mostraram que a imersão do aparelho na solução enzimática foi tão efetiva quanto o regime de higiene anteriormente adotado pelo paciente; porém, quando a imersão foi empregada em combinação com a escovação, a higiene foi mais efetiva. A protease mostrou-se mais efetiva na remoção de pequenas manchas e no fornecimento de uma sensação bucal refrescante.

McCabe, Murray e Kelly ${ }^{63}$ (1995) compararam a eficácia de remoção do biofilme, mancha e cálculo em próteses totais, dos seguintes métodos: imersão utilizando tabletes experimentais Reckitt $\mathrm{GmbH}$ (diluído em água à $35^{\circ} \mathrm{C}$ ) e Steradent (diluído em água à $50^{\circ} \mathrm{C}$ ); escovação com dentifríio Colgate anti-tártaro e com sabonete Cassons Imperial Leather. Os métodos foram testados alternadamente durante 4 semanas. As próteses superiores de 46 pacientes foram inicialmente coradas e o biofilme quantificado pela atribuição de escores. Posteriormente, cada prótese foi higienizada por um profissional com um dos métodos testados e a evidenciação e atribuição de escores novamente realizada. Os agentes de imersão foram utilizados conforme recomendação do fabricante e a escovação realizada durante 2 minutos. A imersão em Steradent foi a forma mais efetiva para remoção de biofilme e manchas. Não houve diferença quanto à capacidade de remoção de cálculo para ambos os produtos. O sabonete foi mais efetivo que o dentifrício na remoção de manchas.

Keng e $\operatorname{Lim}^{53}$ (1996) avaliaram a distribuição do biofilme em 42 próteses totais (superiores e inferiores), e a eficácia de um agente higienizador de imersão à base de peróxido alcalino (Polident - Block Drug Co.). Os pacientes foram orientados a imergir suas próteses 1 vez ao dia em recipiente com 200mL de água corrente e 1 tablete do produto de higiene. Cinco regiões (superfícies externas e internas palatinas, flancos labiais e flancos bucais direito 
e esquerdo) das próteses foram coradas, fotografadas e avaliadas por meio de escala de atribuição de escores. Os resultados mostraram diferenças entre os escores atribuídos, quando foram comparadas as superfícies interna e externa de ambas as próteses (superior e inferior). Isto provavelmente ocorreu, segundo os autores, devido à estagnação salivar e ausência de contato com a língua na superfície interna, favorecendo maior acúmulo de biofilme. O uso isolado do higienizador testado apresentou efetividade limitada, uma vez que houve pequena redução dos níveis de biofilme (34\%). Os achados mostraram que o biofilme tende a se acumular mais rapidamente na superfície interna das próteses, do que nas superfícies polidas. Os autores salientaram a necessidade dos procedimentos de limpeza objetivarem tais áreas específicas e dos procedimentos (laboratoriais e clínicos) resultarem em dentaduras com superfícies mais lisas, facilitando a limpeza.

Cobargas, Cruzat e Mierzo ${ }^{31}$ (1997) testaram a eficácia de dois métodos de higienização na prevenção e controle da Candidíase Atrófica Crônica por meio de testes laboratoriais e clínicos. Cinqüenta pacientes desdentados totais foram distribuídos em 2 grupos de 25 pacientes que realizaram escovação (dentifrício comum e escova dental de cerdas macias) e escovação associada à imersão (peróxido alcalino experimental). O biofilme foi quantificado no $1^{\circ}$ e $15^{\circ}$ dias de experimentação, sendo, evidenciado com eritrosina e a porcentagem de área calculada pelo método visual. No teste laboratorial foram realizadas análises microbiológicas da suspensão de Candida albicans exposta à solução de peróxido. Os resultados mostraram diminuição significativa na inflamação palatina e eliminação da Candida albicans nos testes clínicos. A imersão reduziu cerca de 63\% dos níveis de biofilme em comparação aos 33\% observados no grupo que realizou a escovação como método único.

Kulak et al. $^{54}$ (1997) compararam a efetividade da escovação e da imersão em soluções químicas na remoção da contaminação superficial de próteses totais superiores. A superfície palatina das próteses de 5 pacientes foi seccionada em 8 amostras de $1 \mathrm{~cm}^{2}$. Em 
seguida, seis amostras de cada prótese foram imersas durante o período noturno em soluções efervescentes (Corega, Dentipur, Fittydent), hipoclorito de sódio a 5\%, clorexidina a 1\% (Savlon) ou Ipanol (enxaguatório bucal). Das outras duas amostras, uma foi submetida à escovação com dentifrício e a outra mantida como controle. A efetividade das soluções foi avaliada por meio de microscopia eletrônica de varredura. As fotomicrografias demostraram que todos os métodos de limpeza removeram os microrganismos das superfícies das amostras. No entanto, as soluções de hipoclorito de sódio a 5\% e de clorexidina a 1\% (Savlon) foram significativamente mais efetivas. As soluções efervescentes (Corega, Dentpur e Fittydent) e a escovação foram similares entre si e superiores à imersão em Ipanol. Segundo os autores, a escovação não reduziu eficientemente os contaminantes superficiais das amostras em decorrência das irregularidades da resina acrílica. Os autores concluíram que, apesar do hipoclorito de sódio ter sido efetivo, a clorexidina a $1 \%$ mostrou resultados superiores e, portanto, poderia ser utilizada para imersão das próteses totais durante o período noturno.

Sesma et al. ${ }^{91}$ (1999) investigaram a eficácia de métodos caseiros de higienização de próteses parciais removíveis em microscópio eletrônico de varredura. Foram avaliados 3 métodos por 10 pacientes usuários de próteses parciais removíveis confeccionadas há mais de 2 anos e sem reembasamentos: escovas de dente com dentifrício 3 vezes ao dia, escovas de dente com dentifrício associado à imersão noturna em produto químico à base de perborato de sódio e escovas de dente com dentifrício associado à aplicação noturna de digluconato de clorexidina a 2\% na parte interna da base da prótese, durante 15 minutos. Esses pacientes utilizaram cada método por 1 semana. Para a obtenção dessas amostras, foram realizadas secções de $5 \mathrm{~mm}^{2}$ da região interna das bases das próteses a $1 \mathrm{~cm}$ da borda lateral utilizando-se disco de carburundum sob leve irrigação. A observação do material e as fotos foram realizadas por meio de um microscópio eletrônico de varredura. Pelos resultados observou-se que pelo método 1 , a superfície da resina estava completamente coberta por biofilme 
bacteriano denso. A higienização das próteses com escova e pasta mostrou-se o método menos efetivo. O método 2 melhorou a eficácia na higienização e o método 3 mostrou-se o mais efetivo. Porém, nenhum método avaliado conseguiu eliminar completamente o biofilme bacteriano e remover formações de cálculo aderido à resina da prótese.

Sheen e Harrison ${ }^{95}$ (2000) avaliaram os níveis de biofilme em próteses totais, utilizando imagem digitalizada. Foram selecionados 35 pacientes distribuídos em dois grupos: 1) Higienizador Fixodent (Procter and Gamble Technical Centres Ltd.) à base de polímero de silicone. Os pacientes foram instruídos a dissolver 1 tablete do higienizador em água morna a $35^{\circ} \mathrm{C}$ a $45^{\circ} \mathrm{C}$ em um aparelho denominado Denturette (Procter \& Gamble Technical Centres Ltd.), seguida da escovação com água por 30 segundos uma vez ao dia. 2) grupo controle: água. O período experimental foi de 14 dias e os níveis de biofilme foram avaliados no início, no $2^{\circ}$ e $14^{\circ}$ dias de uso do produto. As próteses totais foram evidenciadas (fluoresceína sódica) e fotografadas. O sistema de imagem consistiu de uma câmera e um sistema de luz ultravioleta fixados sobre uma plataforma, na qual a prótese foi posicionada. Sete imagens foram registradas: superfície labial externa (vista anterior); superfícies bucais externas (direita e esquerda), superfície interna $\left(90^{\circ}\right.$ e $\left.45^{\circ}\right)$ e superfície interna da superfície bucal (direita e esquerda). A avaliação dos níveis de biofilme foi realizada pela análise computadorizada e também pelo método de atribuição de escores. Os resultados mostraram que ambos os métodos foram capazes de quantificar os níveis de biofilme e que o agente higienizador foi efetivo na prevenção do acúmulo de biofilme.

Cobargas, Cruzat e Mierzo ${ }^{31}$ (2001) investigaram a eficácia do uso de dois métodos de higiene (escovação e imersão) avaliando 50 pacientes acometidos de Candidíase Atrófica Crônica. Os pacientes foram distribuídos em dois grupos: 1) utilização de escova dental suave e dentifrício; 2) utilização da escovação e imersão em solução efervescente, três vezes ao dia (após as refeições), durante 10 a 15 minutos. O período experimental foi de 15 dias. A prótese 
total superior (superfícies externa e interna) foi evidenciada (eritrosina) e dividida em zonas: palatinas (anterior e posterior); rebordos alveolares e flancos vestibulares (anteriores e posteriores). O biofilme foi avaliado em cada zona em termos de porcentagem. Os autores observaram que os tabletes potencializaram a ação da escovação convencional e que houve redução de biofilme nas áreas avaliadas.

Gornitsky et $\mathrm{al}^{45}$ (2002) avaliaram a capacidade de remoção de biofilme, manchas e redução de Candida spp.. E bactérias dos agentes de imersão: Denture Brite (efervescente alcalino - Advantege Products - 20 minutos) Polident Overnight (GlaxoSmithKline Consumer Health Group) e Efferdent New Concentrated Blue Tablet Overnight (Pfizer Consumer Health Care) em 27 pacientes idosos hospitalizados. A imersão em água foi usada como agente controle. Testes microbiológicos foram realizados semanalmente durante o uso monitorado de cada produto. O acúmulo de biofilme foi verificado por meio de fotografia dos aparelhos protéticos e atribuição de escores. Foi verificado que os produtos apresentaram resultados similares quanto à eficácia na redução de biofilme e manchas, bem como à ação sobre Candida ou Streptococcus mutans. Concluíram que estes agentes reduzem significantemente o número de microorganismos nas próteses de pacientes hospitalizados, os quais se mostraram incapacitados de higienizar seus aparelhos adequadamente.

Paranhos et al. ${ }^{82}$ (2007a) avaliaram os níveis de biofilme em próteses totais superiores após uso dos seguintes métodos de higiene: 1) Controle: Enxágüe em água corrente; 2) Químico: imersão em solução de peróxido alcalino (Bonyplus, Bonyf AG); 3) Mecânico 1: Escovação após as refeições (escova macia Johnson \& Johnson e dentifrício específico Dentu Creme).; 4) Mecânico-Químico 1: associação dos métodos 2 e 3; 5) Mecânico 2: Escovação após as refeições (escova macia Oral B e dentifrício específico Dentu Creme); 6) MecânicoQuímico 2: Associação dos métodos 2 e 5. Trinta e seis pacientes empregaram todos os métodos por 21 dias, de forma cruzada. Após evidenciação (vermelho neutro 1\%) e fotografia 
das superfícies internas, o biofilme foi quantificado (software Image Tool). Os resultados mostraram diferenças entre os métodos com superioridade dos métodos mecânicos e combinados sobre o método químico. Os autores concluíram que o emprego da escovação, de forma isolada ou combinada com o método químico, pode ser empregada como método efetivo de higiene e, independentemente do método a ser instituído, o profissional deve orientar o usuário de prótese total a respeito das áreas de maior e menor propensão ao acúmulo de biofilme.

\subsubsection{ULTRA-SOM}

Um método alternativo de higiene consiste no desenvolvimento de sistemas mecânicos efetivos. Tais sistemas têm incluído vibradores sônicos, e aparelhos ultrasônicos.

Higienizadores sônicos geram ondas de energia eletrosônica audível dentro de uma faixa especial de audição. Esses aparelhos têm habilidade de limpeza similar aos higienizadores químicos de imersão (MUENCHINGER ${ }^{70}$, 1975). The American Dental Association (ADA) Council on Dental Materials and Devices ${ }^{12}$ (1974-1975) têm relatado que aparelhos ultrasônicos, os que emitem ondas sonoras de alta frequência, podem produzir uma ação de limpeza superior aos higienizadores de imersão ou sônicos (PALENIK; MILLER ${ }^{79}$, 1984).

Higienizadores ultra-sônicos convertem energia elétrica em energia mecânica, em freqüência de ondas sonoras. Essas vibrações induzem à rápida formação e colapso de bolhas microscópicas, as quais produzem uma alta energia que resulta em choques hidráulicos. Esses choques constituem-se na ação de fricção sobre os resíduos da superfície de objetos submersos no líquido contido no interior do aparelho (ABELSON ${ }^{1}$, 1981; BUDTZJØRGENSEN ${ }^{25}$, 1979; COUNCIL ON DENTAL MATERIALS AND EQUIPMENTS ${ }^{33}$, 1983). 
A prótese é colocada dentro de uma unidade, a qual é preenchida com água ou com um agente de imersão indicada pelo fabricante. A higiene de próteses com os aparelhos de ultra-som não é amplamente realizada pelos pacientes, sendo empregada principalmente pelos cirurgiões-dentistas. O tempo pode variar dependendo do aparelho, da solução e da quantidade de manchas ou depósitos a serem removidos (SHAY $\left.{ }^{94}, 2000\right)$. As soluções podem ser trocadas frequentemente e as dentaduras lavadas e escovadas após o procedimento de limpeza ser finalizado. Consiste em procedimento indicado em instituições, como casas de repouso e hospitais. As próteses são colocadas em recipientes próprios, ou mesmo seladas em sacos plásticos e, posteriormente levadas ao aparelho ultra-sônico.

Apesar do desenvolvimento de pesquisas utilizando o aparelho de ultra-som como agente de limpeza de próteses totais, sua eficácia ainda é contraditória. As opiniões se divergem se sua efetividade é atribuída propriamente à ação mecânica do aparelho ou à solução química usada concomitantemente (BUDTZ-JØRGENSEN ${ }^{25}, 1979$ ).

Nicholson et al. ${ }^{76}$ (1968) avaliaram várias substâncias higienizadoras de dentaduras combinadas ou não com um aparelho de ultra-som e constataram uma superioridade das soluções. Para o teste, foram inicialmente examinadas 96 próteses totais superiores e inferiores. Destas, foram selecionadas 24 contendo depósitos pesados de biofilme que foram fotografadas (superfície externa) com filme preto e branco e colorido (diapositivos), antes e após o tratamento. Tais fotografias foram ampliadas e os depósitos (biofilme, cálculo e pigmentações) quantificados. Foram preparados 6 imersões contendo soluções de hipoclorito de sódio e peróxidos alcalinos (comerciais e experimentais) combinadas ou não com o aparelho de ultra-som. O período de imersão foi de 10 minutos. Os resultados mostraram que o uso do ultra-som associado à água não foi efetivo, levando à conclusão de que a limpeza dos aparelhos protéticos estava relacionada à atividade química das soluções (principalmente ao hipoclorito), com pouca relação à atividade vibratória do aparelho mecânico. 
Myers e $\mathrm{Krol}^{74}$ (1974) testaram a eficácia da ação ultra-sônica em dentaduras de 8 pacientes que apresentavam depósitos leves a moderados de cálculos. Durante 4 semanas consecutivas foram realizadas fotografias da superfície externa das próteses (totais duplas e parciais removíveis inferiores), sendo que nas duas primeiras semanas os pacientes utilizaram o ultra-som com uma solução contendo fosfato alcalino, e nas restantes, realizaram o método usual de higienização (escovação com escova para dentadura por 1 minuto). Cinco fotografias (flancos bucais, labiais e sublinguais) foram realizadas por técnico especializado: no início e em cada visita subseqüente. Foram obtidas informações a respeito dos hábitos alimentares, consumo de bebida alcóolica, fumo, higiene, uso da prótese (uso noturno, diurno e armazenamento), consumo de medicamentos e tipo de material utilizado (dentes e base). Os resultados mostraram que a solução contendo fosfato foi mais efetiva na remoção de cálculos e manchas. Os autores concluíram que o higienizador ultra-sônico associado à solução de limpeza (fosfato alcalino) foi efetivo na remoção de cálculos nas várias situações clínicas, sem danos ao aparelho protético. Foram removidas também manchas de cigarro e café. Após descontinuidade do uso do aparelho, houve tendência ao acúmulo de cálculos e manchas.

Shannon e Starcke ${ }^{93}$ (1978) conduziram testes laboratoriais e clínicos para testar a habilidade de remoção de biofilme de produtos de higiene específicos para próteses totais. Nos testes laboratoriais, amostras de resinas acrílicas foram cobertas por depósitos salivares e tratadas com: Mersene (hipoclorito alcalino - Colgate-Palmolive Co); VA Denture Cleanser (perborato, fosfato e organic chloride); Polident (peróxido alcalino - Block Drug Co); Água e aparelho ultra-sônico (Cooper Laboratories) associado à solução ultra-sônica. As imersões foram realizadas por 15 minutos. Após tratamento, as amostras foram evidenciadas com azul de metileno por 15 minutos e classificadas de acordo com escala de escores. Nos testes clínicos, três produtos de imersão, New Mersene (hipoclorito alcalino - Colgate-Palmolive Co); Purify (enzima - Johnson \& Johnson) e VA Denture Cleanser (perborato, fosfato e 
cloreto orgânico) foram testados em próteses totais de 4 pacientes por um período de 10 dias. O período de imersão foi de 8 horas (“overnight”). Ao final do período experimental, as próteses foram evidenciadas com azul de metileno e fotografadas para avaliação dos níveis de biofilme, de acordo, também, com a escala de escores. Os resultados laboratoriais mostraram que o Mersene e VA foram mais efetivos. O uso do ultra-som isolado ou associado à solução de imersão foi mais efetivo que o Polident e menos efetivo que o Mersene e VA. Não houve diferença quando comparou-se o uso do ultra-som (associado à solução ultra-sônica) com as imersões isoladas. Os resultados mostraram que os produtos de imersão mantiveram as próteses em bom estado de higiene, sem a necessidade de escovação. Os resultados clínicos mostraram que o Mersene e VA foram mais efetivos, porém em soluções “overnight” e que a habilidade da solução sônica não foi aumentada com o uso do ultra-som.

Abelson $^{1}$ (1981), para testar a habilidade da remoção de biofilme de um novo aparelho de ultra-som (Sonic Scrub) usando somente água ou soluções de peróxido alcalino: Efferdent (Warner Lambert Co) ou Polident (Block Drug Co), examinou 18 usuários de próteses totais. Foram realizadas três sessões, onde os pacientes ficaram três dias sem higienizar seus aparelhos antes de cada sessão. Na primeira sessão, as dentaduras foram cuidadosamente limpas para início dos testes e cada produto foi utilizado de acordo com as instruções do fabricante. Foram utilizados três critérios de atribuição de escores para quantificar os níveis de biofilme: 1) Número de dentes apresentando biofilme; 2) Índice específico de biofilme, aplicado em seis dentes artificiais previamente selecionados; 3) Índice específico de biofilme, aplicado na superfície tecidual da prótese. Os resultados mostraram a superioridade do ultrasom (dentes e base) quando usado com água em relação às duas soluções higienizadoras do tipo imersão. A ação de limpeza foi relacionada somente à cavitação sônica, não propriamente às soluções químicas. 
Gwinnett e Caputo $^{47}$ (1983) também avaliaram um aparelho ultra-sônico usando, porém, técnicas laboratoriais com microscopia eletrônica de varredura. Foram confeccionadas 3 próteses totais superiores e 7 fragmentos de cada próteses (contendo dentes e base) foram colocadas em recipientes contendo saliva de 6 indivíduos, com a finalidade de precipitar a camada de proteína salivar e esta atuar como substrato para adesão de microorganismos. Foi inoculado $S$. mutans em amostras de resina acrílica (base e dentes). O biofilme bacteriano foi preparado por 72 horas e foram usados como comparação, além do aparelho de ultra-som (Sonic Scrub - Clairol, Inc.), soluções químicas do tipo imersão (Extra Strenght Efferdent Warner Lambert; e Polident Extra Effervescent Action - Block Drug Co). Os resultados mostraram que o Polident comportou-se similarmente ao Efferdent, permanecendo nos fragmentos das próteses uma grande quantidade de biofilme e microorganismos. O ultra-som comportou-se diferentemente dos dois produtos de imersão, deixando a superfície limpa e livre de microorganismos. Os autores salientam porém que, apesar da efetividade do aparelho sobre o S. mutans, podem existir diferenças microbianas do biofilme formado "in vivo" daquele formado “in vitro”, salientando a necessidade de estudos clínicos.

Palenik e Miller $^{79}$ (1984) compararam a efetividade de dois aparelhos ultra-sônicos, Sonic-Scrub (Clairol - 250mL de água a $13^{\circ} \mathrm{C}$ (Cold Water) $+27,5 \mathrm{~mL}$ de enxaguatório bucal por 15 minutos) e Model CU-6 Branson Ultrasonic Cleaner (250mL de água em $40^{\circ} \mathrm{C}$ a $42^{\circ} \mathrm{C}$ + 27,5mL de enxaguatório bucal comercial Lavois em 5, 10 ou 15 minutos) e um agente de imersão à base de hipoclorito alcalino (Efferdent - 200mL de água a $48^{\circ} \mathrm{C}$ por 12 minutos). Trinta próteses totais superiores, com tempo de uso mínimo de dois anos, foram esterilizadas com óxido de etileno e utilizou-se o Streptococcus mutans para formação de biofilme na superfície do acrílico. Após instalação do biofilme (18 a 20 horas), as próteses foram imersas em evidenciador (fluoresceína sódica a 0,5\%) por um minuto. Todas as superfícies das próteses totais superiores foram avaliadas, sendo que, para a atribuição de escores, cada 
prótese foi dividida em três grandes áreas: dentes, palato e superfície tecidual. Cada um desses grandes segmentos foi posteriormente dividido em 40 partes iguais (forma quadrangular). Os escores provenientes de cada área quadrangular foram avaliados e somados para obtenção de uma média. Em seguida, a média dos escores, proveniente das grandes áreas, foi somada e considerada para obtenção do escore total de biofilme para cada prótese avaliada. O método ultra-sônico mostrou-se mais efetivo que o efervescente, sendo que o modelo Branson Ultrasonic Cleaner foi o mais efetivo.

Raab et al. ${ }^{86}$ (1991), comparando a eficácia de dois métodos de limpeza, imersão em solução de peróxido alcalino (Extra Strenght Efferdent - Warner Lambert) e ultra-som (L \& R Transister/Ultrasonic T-28 - L \& R Mfg. Co - 90 segundos) na habilidade de remoção de depósitos superficiais (biofilme, cálculo e pigmentação de nicotina), empregaram metodologia de quantificação utilizando microscópio eletrônico de varredura. Foram preparadas 30 amostras de resina acrílica provenientes de 10 próteses totais seccionadas para exame em microscópio eletrônico de varredura (Phillips 500). Um grupo ficou sem limpeza. Foram realizadas fotografias (80X e 5000X) de regiões representativas de cada amostra, sendo que cada fotografia foi graduada em uma escala de 1 (superfície limpa) a 10 (superfície totalmente contaminada) de acordo com a porcentagem de área recoberta com os depósitos. Os resultados mostraram que houve diferença significativa entre os três tratamentos (controle, imersão e ultra-som), com superioridade do ultra-som. O ultra-som ofereceu um método de limpeza rápido, barato e simples para pacientes debilitados, necessitando de maior número de experimentos clínicos, objetivando testes de sua efetividade. 
O objetivo deste trabalho é:

1. Avaliar clinicamente a capacidade de remoção do biofilme de próteses totais dos seguintes métodos de higiene:

1.1 Método Químico: Pastilha efervescente para imersão de próteses totais à base de peróxido alcalino (Corega Tabs - Block Drug Company, Inc. - USA);

1.2 Método Mecânico: aparelho ultra-sônico (Ultrasonic Cleaner - Odontobrás modelo 2840D - Ind. E Com. Equip. Méd. Odont. Ltda, Ribeirão Preto, São Paulo, Brasil);

1.3 Método Associado: Associação dos métodos químico (pastilha efervescente) e mecânico (aparelho ultra-sônico). 
4. MATERIAL E MÉTODOS 


\subsection{Seleção dos pacientes}

Após a aprovação do projeto de pesquisa pelo Comitê de Ética da Faculdade de Odontologia de Ribeirão Preto - USP (processo n 2003.1.1369.58.4) e assinatura do Termo de Consentimento foram selecionados 80 pacientes da clínica de Prótese Total, 16 homens e 64 mulheres, com idade entre 45 e 80 anos, estado de saúde geral bom, usuários de próteses totais superiores confeccionadas em resina acrílica termicamente polimerizada e dentes artificiais de acrílico. O tempo de uso era de 1 a 10 anos.

Com relação à presença de biofilme, as próteses foram selecionadas de acordo com o Índice Aditivo (Ambjørnsen et al. ${ }^{9}, 1982$ ), da seguinte forma:

A. As próteses totais eram removidas da cavidade oral dos pacientes e enxaguadas em água corrente por 5 segundos para remoção do excesso de saliva e secas com um jato de ar por 10 segundos;

B. As superfícies internas eram divididas visualmente em cinco áreas: papila incisiva; duas áreas localizadas lateralmente a $1 \mathrm{~cm}$ da linha mediana e áreas posteriores de ambas as tuberosidades (figura 1).

C. Cada área era visualmente limitada com um círculo de $1 \mathrm{~cm}$ de diâmetro e, posteriormente avaliada quanto à presença de biofilme, sob iluminação do refletor de luz do equipamento odontológico;

D. A avaliação da presença de biofilme era realizado por meio da atribuição de escores para cada área, os quais variavam de 0 a 3: escore 0: sem biofilme; escore 1: biofilme visível ao raspar a superfície com instrumento rombo; escore 2: acúmulo de biofilme moderado, visível na presença de luz; escore 3: acúmulo abundante de biofilme. 
E. Foram selecionadas as próteses com escore igual ou maior que 1 para cada área.

Figura 1 - Representação da aplicação do Índice Aditivo de

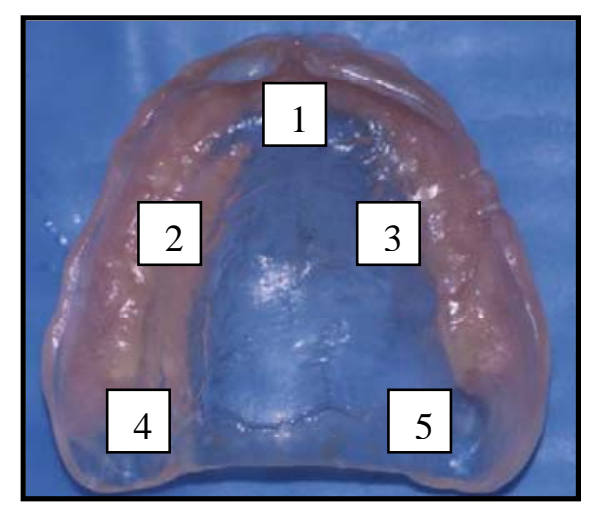

\subsection{Métodos de Higiene e Delineamento Experimental}

O período experimental foi de 21 dias, sendo que os pacientes foram distribuídos em 04 grupos $(n=20)$ :

\section{1) Controle:}

a) Escovação das próteses totais por dois minutos, 3 vezes ao dia, após as refeições (café, almoço e jantar) com escova específica para próteses totais (Bitufo, Itupeva, São Paulo, Brasil - Figura 2) e água corrente;

b) Enxágüe da cavidade oral com água corrente, após cada escovação das próteses;

c) Manutenção das próteses imersas em água durante o período do sono.

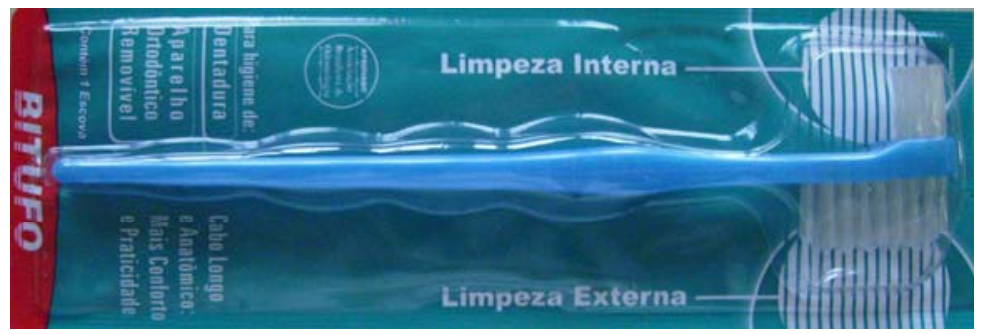

Figura 2 - Escova Bitufo

\section{2) Método Químico:}

a) Escovação das próteses totais por dois minutos, 3 vezes ao dia, após as refeições (café, almoço e jantar) com escova específica para próteses totais (Bitufo, Itupeva, São Paulo, Brasil) e água corrente;

b) Enxágüe da cavidade oral com água corrente, após cada escovação das próteses; 
c) Imersão diária das próteses em recipiente contendo 1/2 copo de água morna e 01 pastilha efervescente de peróxido alcalino (Corega Tabs - Block Drug Company, Inc. - USA figura 3) por 5 minutos após o jantar;

d) Enxágüe das próteses em água antes da inserção na cavidade oral.

e) Manutenção das próteses imersas em água durante o período do sono.

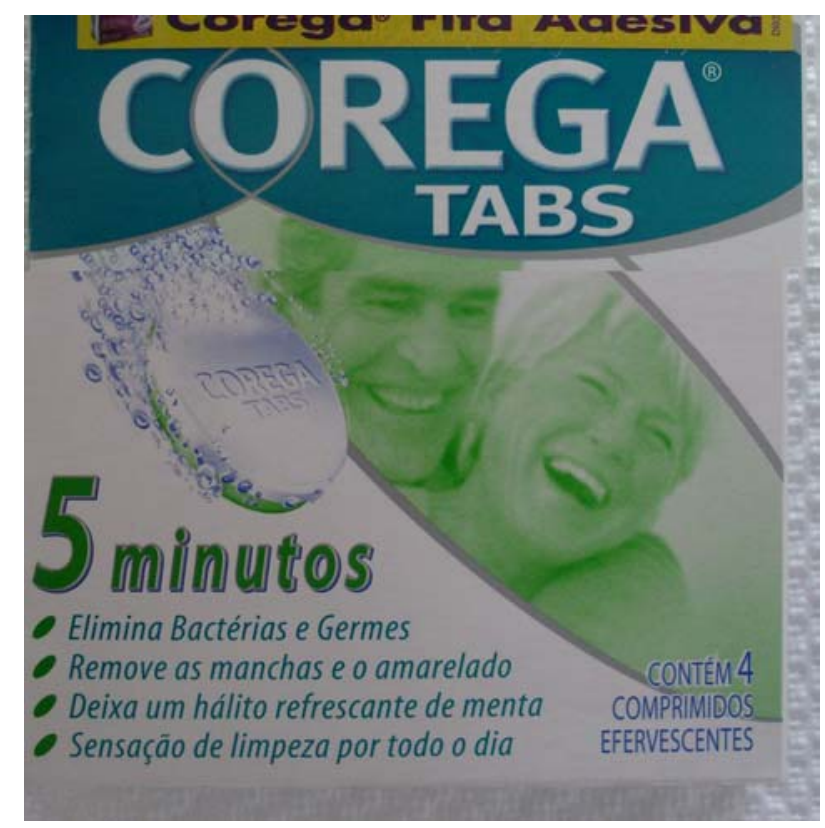

Figura 3 - Pastilha efervescente Corega tabs.

\section{3) Método Mecânico:}

a) Escovação das próteses totais por dois minutos, 3 vezes ao dia, após as refeições (café, almoço e jantar) com escova específica para próteses totais (Bitufo, Itupeva, São Paulo, Brasil) e água corrente;

b) Enxágüe da cavidade oral com água corrente, após cada escovação das próteses;

c) Manutenção das próteses imersas em água durante o período do sono.

d) Ao final do experimento (21 dias), imersão das próteses em 250mL de água esterilizada dentro de um becker esterilizado de $600 \mathrm{~mL}$ e vedado com filme PVC e agitação ultra-sônica (Ultrasonic Cleaner - Odontobrás - modelo 2840D - Ind. E Com. Equip. Méd. 
Odont. Ltda - Ribeirão Preto, São Paulo, Brasil- figuras 4 e 5) por 15 minutos realizada pelo profissional.

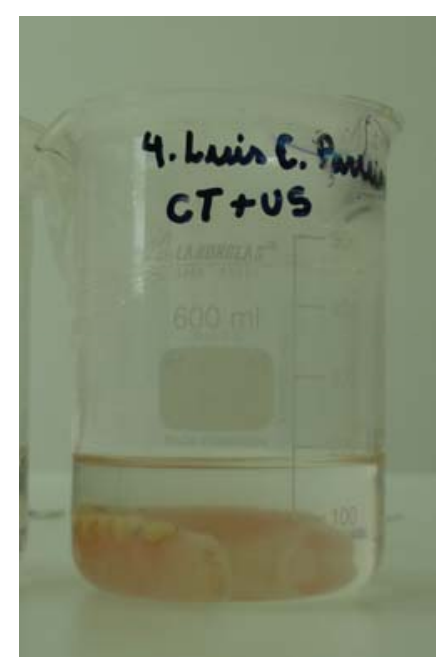

Figura 4 - Prótese imersa em água esterilizada.

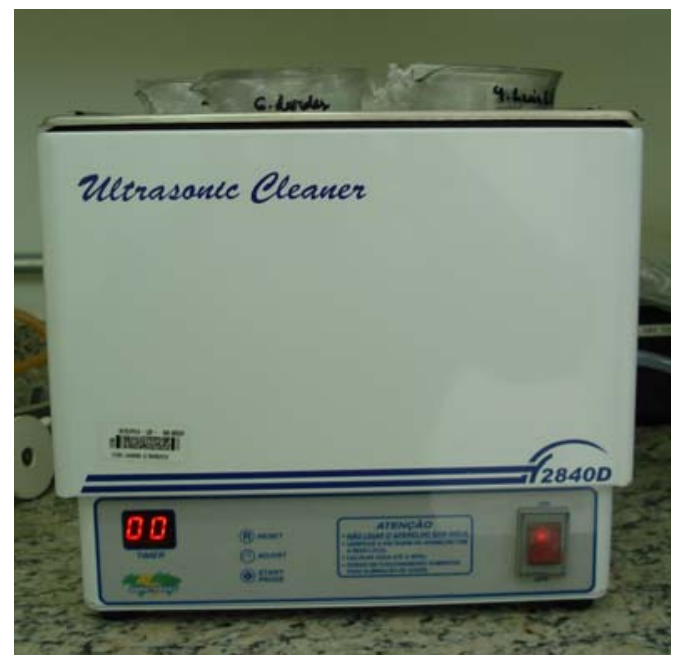

Figura 5 - Aparelho Ultra-sônico com as próteses

\section{4) Método Associado:}

a) Escovação das próteses totais por dois minutos, 3 vezes ao dia, após as refeições (café, almoço e jantar) com escova específica para próteses totais (Bitufo, Itupeva, São Paulo, Brasil) e água corrente;

b) Enxágüe da cavidade oral com água corrente, após cada escovação das próteses;

c) Imersão diária das próteses em recipiente contendo 1/2 copo de água morna e 01 pastilha efervescente de peróxido alcalino (Corega Tabs - Block Drug Company, Inc. - USA) por 5 minutos após o jantar;

d) Enxágüe das próteses em água antes da inserção na cavidade oral.

e) Manutenção das próteses imersas em água durante o período do sono.

f) Ao final do ciclo (21 dias), imersão das próteses em aparelho ultra-sônico (Ultrasonic Cleaner - Odontobrás - modelo 2840D - Ind. E Com. Equip. Méd. Odont. Ltda - Ribeirão Preto, São Paulo, Brasil) por 15 minutos realizada pelo profissional. 


\subsection{AVALIAÇÃO DA CAPACIDADE DE REMOÇÃO DO BIOFILME}

\subsubsection{Evidenciação do Biofilme e Fotografia das Próteses}

Após a remoção das próteses da cavidade oral do paciente, elas foram enxaguadas em água esterilizada (5 segundos - figura 6) e secas por um jato de ar (10 segundos - figura 7). As superfícies internas das próteses totais superiores foram evidenciadas com a utilização de Vermelho neutro a 1\% por meio de um cotonete seco (figuras 8 e 9). Em seguida, as próteses foram novamente enxaguadas em água esterilizada (5 segundos - figura 10) para remoção do excesso de evidenciador e secas (10 segundos - figura 11).
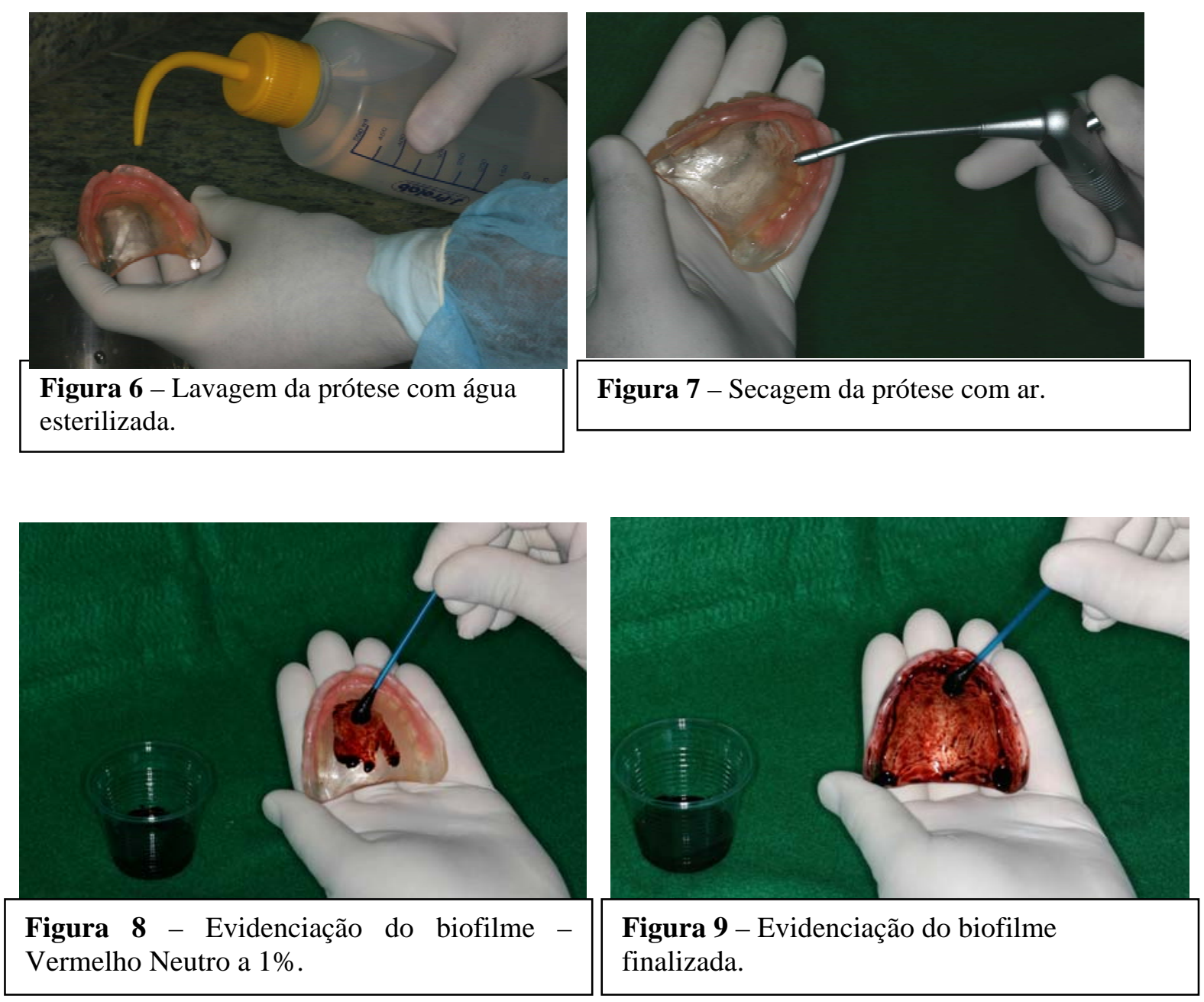

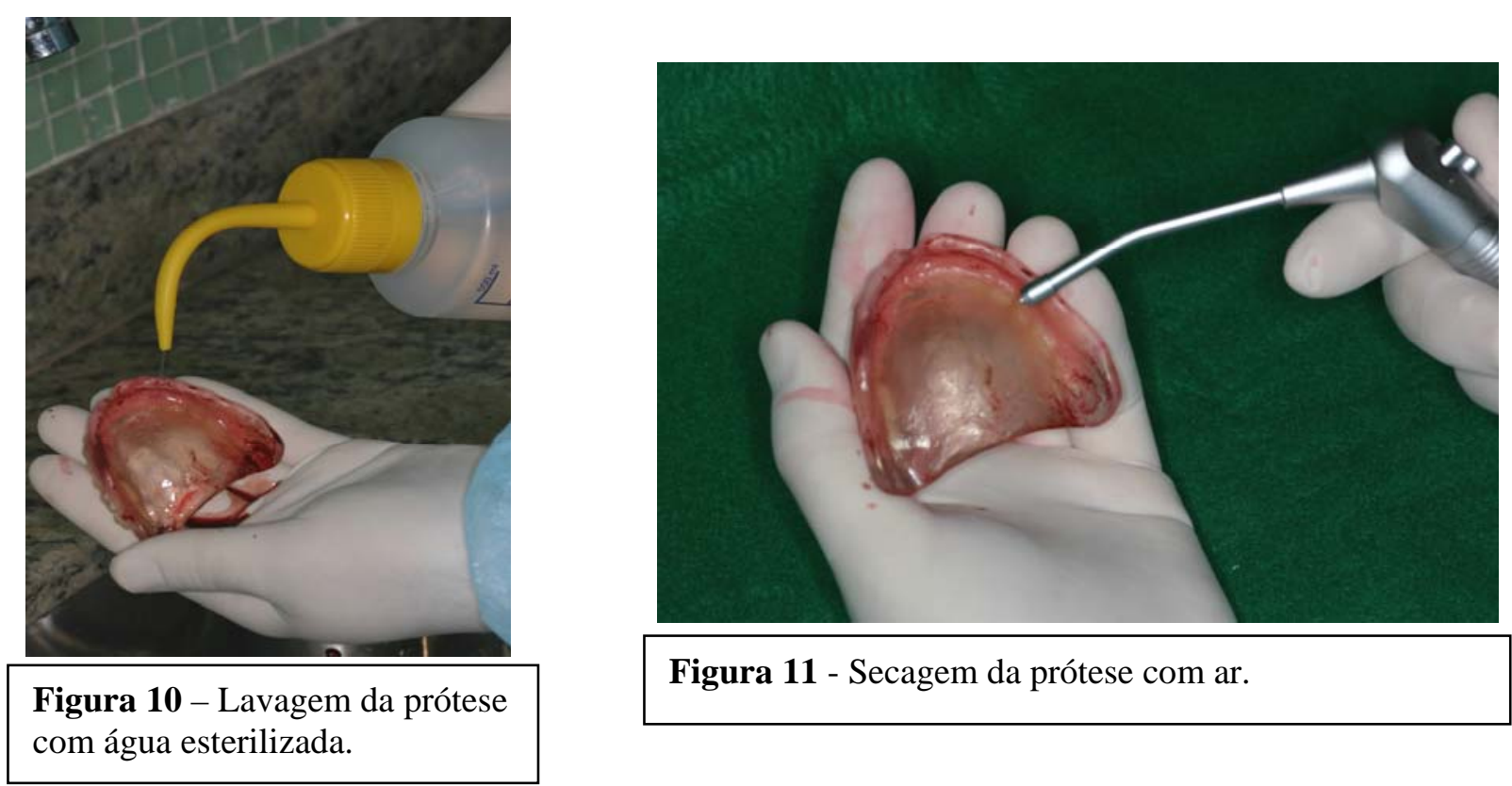

Figura 11 - Secagem da prótese com ar.

\subsubsection{Quantificação do Biofilme}

As próteses coradas foram fotografadas com uma câmara fotográfica digital (Canon EOS Digital Rebel EF-S 18-55, Canon Inc., Tokyo, Japão) e flash (Canon MR-14 EX, Canon Inc., Tokyo, Japão) com distância filme-objeto e tempo de exposição padronizados, com o posicionamento da máquina fotográfica em estativa (CS-4 Copy Stand, Testrite Inst. Co., Inc., Newark, NJ, USA) (figura 12 ) com angulação de $45^{\circ}$.

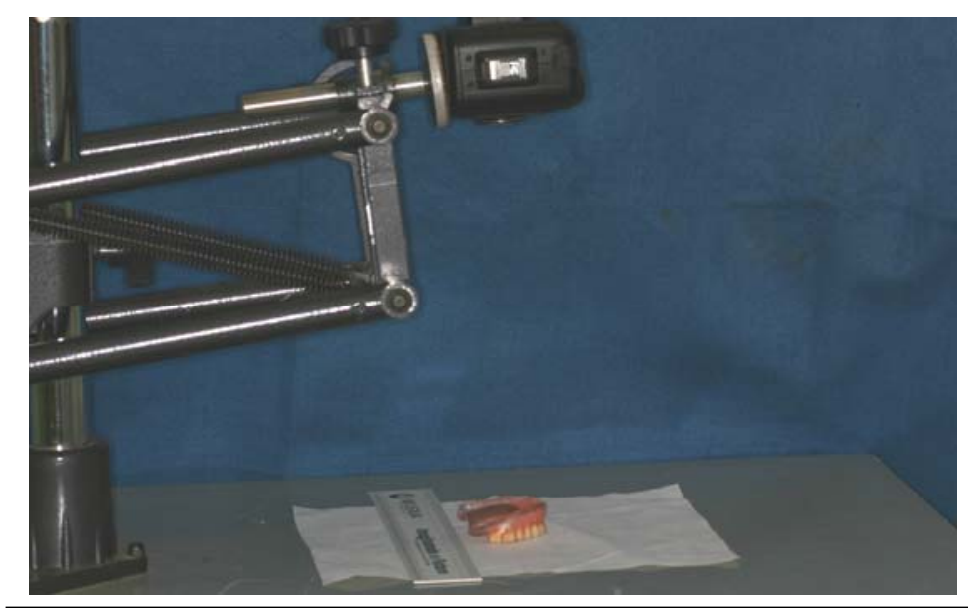

Figura 12 - Prótese posicionada para fotografia da superfície interna. 
As fotografias foram transferidas para um computador (Intel S478 P4 2.8), processadas no Adobe Photoshop 5.5 e as medidas (área total da superfície interna e corada com biofilme) foram realizadas com o programa Image Tool (Windows, versão 2.02, The University of Texas Health Science Center).

A figura 13 apresenta a tela principal do Image Tool. Para obtenção da imagem a ser medida, o cursor era posicionado no ícone "File - Open Image”.

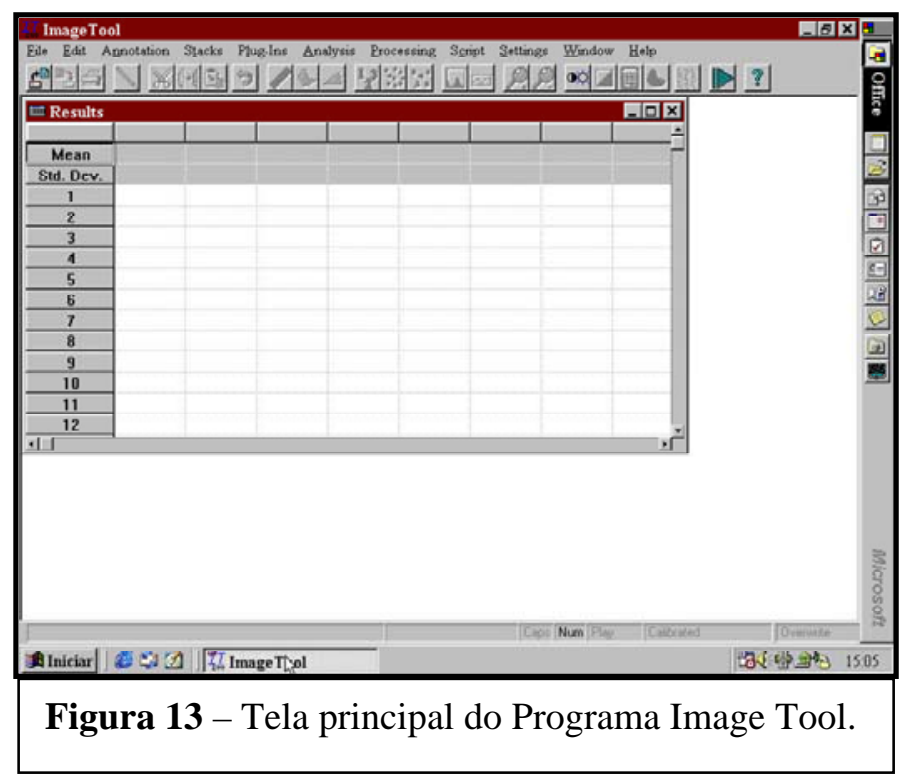

Na seqüência, o cursor foi posicionado no ícone "Settings - Calibrate Spatial Measurements” para realização da calibração da unidade de medida.

A figura 14 mostra o posicionamento do cursor na régua utilizada na fotografia.

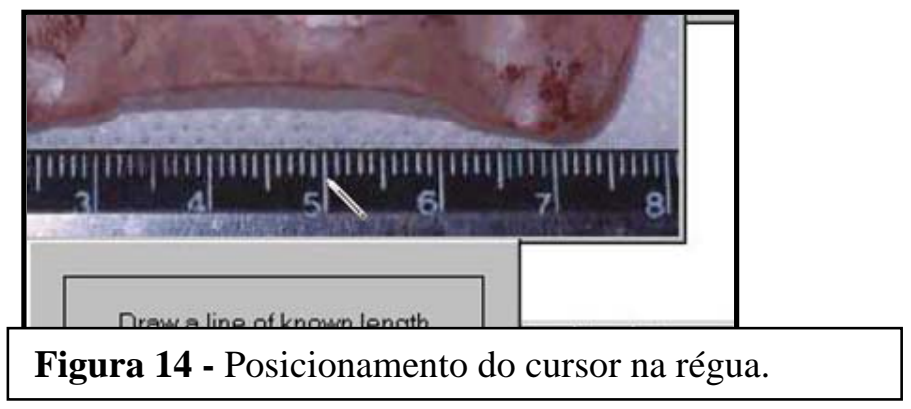


Após a indicação da referência espacial (na régua), aparecia uma janela para que fossem selecionadas a grandeza e a unidade de medida a serem utilizadas. Uma vez calibrada a unidade de medida, levava-se o cursor sob o ícone ANALYSIS para obter a ferramenta de medição da área desejada.

A figura 15 mostra o início da delimitação da área a ser medida na superfície interna.

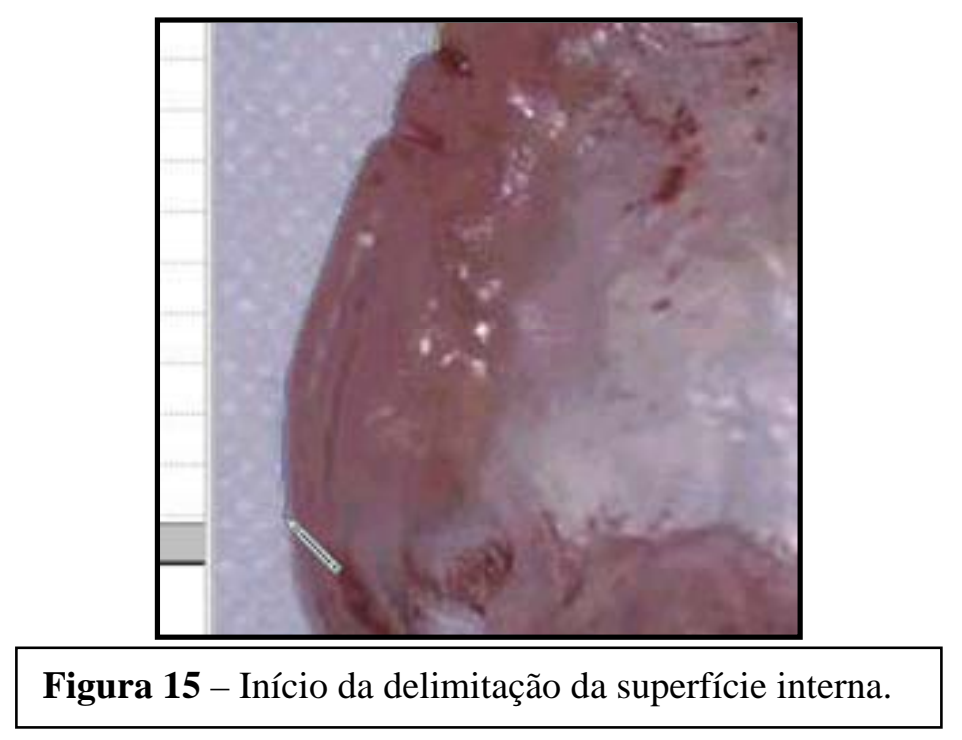

Terminada a delimitação da área interessada, eram dados dois toques no botão esquerdo do “mouse” para obtenção da medida, que aparecia na planilha posicionada em segundo plano (à imagem) no software Image Tool.

Para prosseguir com a medição das áreas pelo evidenciador, novamente a ferramenta de medição da área era obtida.

A figura 16 apresenta a delimitação de uma das áreas coradas. 


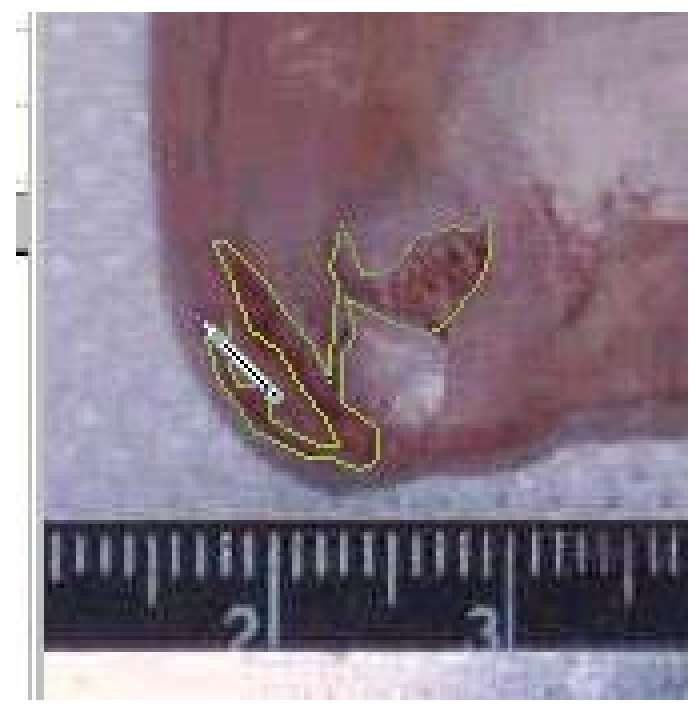

Figura 16 - Delimitacão de área corada - Região Dosterior.

Terminado o contorno da área corada, eram dados dois toques com o botão esquerdo do "mouse" para obtenção da medida em $\mathrm{cm}^{2}$ (observar medida obtida na planilha de resultados) e iniciava-se a medição da área corada seguinte (Figura 17);

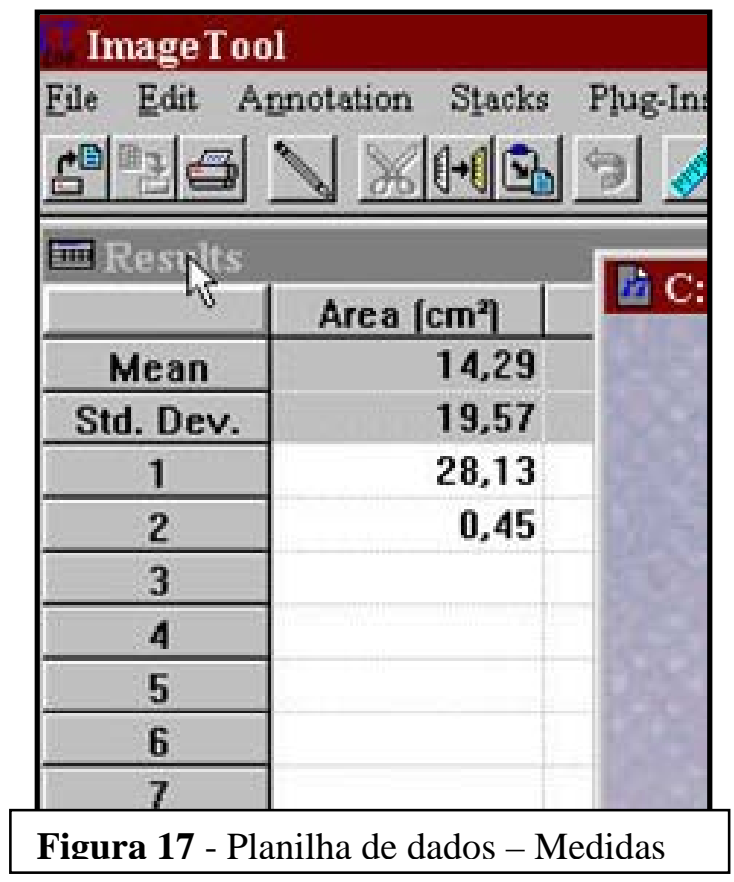

As áreas coradas eram medidas uma a uma, e os resultados apresentados na planilha, eram somados. 
Finalizadas as medições das áreas (total e biofilme), a porcentagem da superfície recoberta pelo biofilme de cada prótese total $(\mathrm{X})$ foi calculada como sendo a relação entre a área do biofilme multiplicado por 100 e área da superfície total da base interna da prótese (Fernandes et al. ${ }^{42}$, 2006; Silva-Lovato; Paranhos $^{97}$, 2006; Salles et al. ${ }^{89}$, 2006; Paranhos et al. $\left.{ }^{83}, 2007 b\right)$.

$$
\begin{aligned}
& \mathrm{X}=\underline{\text { área da superfície recoberta pelo biofilme }} \\
& \text { área da superfície total da base interna da prótese }
\end{aligned}
$$

Antes e após o uso dos produtos por 21 dias, após a quantificação do biofilme, procedia-se a escovação das próteses com escova específica (Denture - Condor S.A., Santa Catarina, Brasil - figura 18) e sabonete líquido (JOB Química, Produtos para limpeza Ltda., Monte Alto, SP, Brasil), tendo como objetivo, a eliminação total do biofilme. Terminada a escovação, as próteses eram enxaguadas em água corrente e devolvidas aos pacientes.

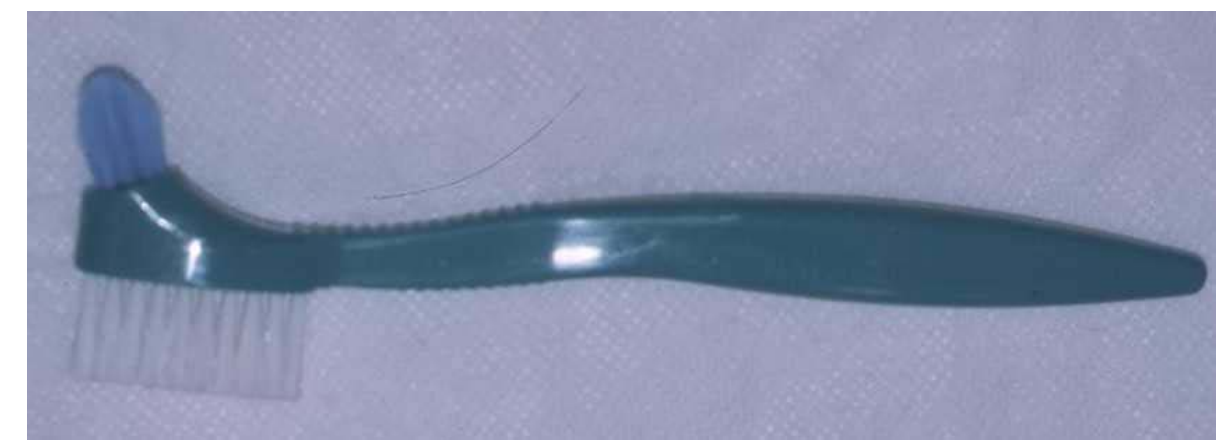

Figura 18 - Escova Denture. 
5. RESULTADOS 
Os resultados originais das áreas (total e biofilme) das superfícies internas das próteses totais superiores, empregando o método quantitativo Image Tool, após 21 dias de uso dos produtos estão apresentados no Apêndice A (tabela A1). As porcentagens de biofilme obtidas estão apresentadas na tabela 1.

Tabela 1: Porcentagens de biofilme após o uso de cada método testado por 21 dias.

\begin{tabular}{c|c|c|c}
\hline Controle & $\begin{array}{c}\text { Químico } \\
\text { (Corega) }\end{array}$ & $\begin{array}{c}\text { Mecânico } \\
\text { (Ultra-Som) }\end{array}$ & $\begin{array}{c}\text { Associado } \\
\text { (Corega + Ultra Som) }\end{array}$ \\
\hline 41,10 & 5,48 & 41,64 & 16,07 \\
29,46 & 21,73 & 7,16 & 2,96 \\
54,62 & 26,61 & 10,36 & 18,70 \\
36,78 & 56,36 & 24,69 & 41,80 \\
27,97 & 14,03 & 0,00 & 12,46 \\
13,74 & 25,76 & 7,65 & 28,43 \\
35,17 & 41,98 & 4,28 & 4,55 \\
15,63 & 13,58 & 13,98 & 27,15 \\
50,83 & 42,71 & 8,06 & 0,00 \\
40,40 & 15,21 & 39,92 & 52,53 \\
43,44 & 7,78 & 38,96 & 8,67 \\
12,88 & 7,40 & 16,42 & 0,00 \\
62,20 & 6,66 & 15,97 & 0,50 \\
24,64 & 24,98 & 12,45 & 0,00 \\
79,27 & 39,89 & 15,92 & 1,26 \\
18,92 & 3,89 & 7,76 & 1,21 \\
22,07 & 1,12 & 12,05 & 15,68 \\
88,64 & 1,76 & 10,81 & 18,29 \\
72,78 & 6,05 & 20,89 & 6,29 \\
16,52 & 5,18 & 5,53 & 6,14 \\
\hline
\end{tabular}

Testes estatísticos foram realizados, verificando-se que os dados originais obtidos não eram normais (Apêndice B), sendo necessário o emprego de uma análise não paramétrica. O teste estatístico empregado foi o de Kruskal-Wallis (Anexo 1 - Tabela 2).

Tabela 2 - Teste de Kruskal-Wallis

\section{Fator de Variação Único: Métodos}

Valor (H) de Kruskal-Wallis calculado

Valor de $\mathrm{x}^{2}$ para 3 graus de liberdade 21.1795 Probabilidade de H0 para esse valor 
Os resultados do teste de Kruskal-Wallis mostraram haver diferença significante entre os métodos. As médias e os resultados das comparações estão apresentados nas tabelas 3 e 4, respectivamente.

Tabela 3 - Teste de Kruskal-Wallis - Médias dos Postos das amostras.

\begin{tabular}{l|c|c}
\hline \multicolumn{3}{c}{ MÉDIAS DOS POSTOS DAS AMOSTRAS } \\
\hline Amostra & Soma de Postos & Média \\
\hline Controle & 1211 & 60.5 \\
Químico & 744 & 37.2 \\
Mecânico & 704 & 35.2 \\
Associado & 582 & 29.1 \\
\hline
\end{tabular}

Tabela 4 - Teste de Kruskal-Wallis - Comparação entre médias dos postos das amostras.

\begin{tabular}{|c|c|c|c|c|c|}
\hline \multirow{2}{*}{$\begin{array}{c}\text { Amostras } \\
\text { comparadas }\end{array}$} & \multirow{2}{*}{$\begin{array}{c}\text { Diferença } \\
\text { entre médias }\end{array}$} & \multicolumn{3}{|c|}{ Valores críticos $(\alpha)$} & \multirow[t]{2}{*}{ Significância } \\
\hline & & 0.05 & 0.01 & 0.001 & \\
\hline Controle X Químico & 23.3500 & 12.7843 & 16.9751 & 22.0272 & $0.1 \%$ \\
\hline Controle X Mecânico & 25.3750 & 12.7843 & 16.9751 & 22.0272 & $0.1 \%$ \\
\hline Controle X Associado & 31.4750 & 12.7843 & 16.9751 & 22.0272 & $0.1 \%$ \\
\hline Químico X Mecânico & 2.0250 & 12.7843 & 16.9751 & 22.0272 & ns \\
\hline Químico X Associado & 8.1250 & 12.7843 & 16.9751 & 22.0272 & ns \\
\hline Mecânico X Associado & 6.1000 & 12.7843 & 16.9751 & 22.0272 & ns \\
\hline
\end{tabular}

ns $=$ não significante.

O método controle apresentou as maiores médias, sendo estatisticamente diferente dos demais, que foram igualmente eficazes entre si. 
Uma das medidas da efetividade de um agente higienizador de dentadura é sua habilidade de remoção de biofilme. Nikawa et al. ${ }^{77}$ (1999) chamam a atenção da necessidade desta efetividade ser avaliada por meio de testes clínicos e laboratoriais, pois os resultados in vitro não necessariamente concordam com os testes in vivo. Em relação aos higienizadores de próteses totais, os estudos clínicos prevalecem sobre os laboratoriais.

Em experimentos clínicos, os níveis de biofilme podem ser avaliados no aparelho protético como um todo, isto é, sem distinção entre uma superfície ou outra (HUTCHINS; PARKER $^{50}$, 1973; MYERS; KROL ${ }^{74}, 1974$; SHANNON; STARCKE ${ }^{93}$, 1978). Porém, na maioria deles, essa avaliação é realizada na superfície interna da prótese total superior. Em alguns estudos, além da superfície interna, outras superfícies são incorporadas, principalmente os flancos bucais superiores (AUGSBURGER; ELAHI ${ }^{15}$, 1982; KENG; LIM ${ }^{53}$, 1996; McCABE et al. ${ }^{64}, 1996$; NICHOLSON; STARK; SCOTT $^{76}, 1968$; PARANHOS et al. ${ }^{80}, 2000$; SHEEN; HARRISON ${ }^{95}$, 2000; SILVA-LOVATO; PARANHOS ${ }^{97}$, 2006; TARBET et al. ${ }^{100}$, 1984). A análise de ambas as próteses (superior e inferior) também é relatada (MURRAY; McCABE; STORER ${ }^{72}$, 1986; PIETROKOVSKY et al. ${ }^{84}$, 1995), porém mais freqüentemente em estudos de levantamentos epidemiológicos.

Neste estudo, a efetividade dos produtos foi avaliada nas superfícies internas de próteses superiores, por constituir-se em área de grande acúmulo de biofilme e de grande importância clínica em relação às patologias encontradas em usuários de próteses totais. A análise da superfície externa não foi incorporada, pelo fato de constituir-se em área de maior facilidade de higienização e com níveis mais baixos de biofilme, que a correspondente interna (FERNANDES et al. ${ }^{42}$, 2006; JEGANATHAN et al. ${ }^{52}$, 1996; KENG; LIM ${ }^{53}$, 1996; McCABE et al. ${ }^{64}, 1996$; PARANHOS et al. ${ }^{80}, 2000$; PIETROKOVSKI et al. ${ }^{84}, 1995$; SILVA-LOVATO; PARANHOS $\left.^{97}, 2006\right)$. 
O evidenciador utilizado foi o vermelho neutro por ter afinidade com o biofilme e ser de fácil remoção (SILVA; PARANHOS; ITO ${ }^{96}$, 2002). Buscando uma análise objetiva, utilizou-se metodologia fotográfica (AMBJØRNSEN; RISE; HAUGEJORDEN ${ }^{10}$, 1984) e análise quantitativa (PARANHOS; SILVA ${ }^{81}$, 2004) dos depósitos de biofilme.

Levantamentos confirmam que o método mecânico de higiene ainda é o mais popular entre usuários de próteses totais (MARCHINI et al. ${ }^{60}$, 2004; MARCHINI et al. ${ }^{61}$, 2006; NIKAWA et al. $\left.^{77}, 1999 ;\right)$. A imersão em soluções efervescentes de peróxidos alcalinos é também amplamente empregada (ADVERTISING AGE ${ }^{7}, 1978$; $\mathrm{SHAY}^{94}$, 2000). Jagger e Harrison $^{51}$ (1995), em levantamento de 120 usuários de próteses totais e parciais removíveis, demonstraram que, aproximadamente 35\% usavam higienizador químico em forma de tabletes efervescentes, como parte da rotina diária de higiene.

No Brasil, uma pequena parcela da população utiliza tal método como auxiliar de limpeza. Apesar de controverso, isto pode ser explicado pela falta de acesso aos materiais de natureza química, pois são pouco comercializados, ou mesmo pelo fator custo. Uma causa que pode ser apontada também é a própria falta de conhecimento, por parte dos pacientes, desse método como coadjuvante na limpeza da prótese total (CUMMING et al. ${ }^{37}$, 1990; JAGGER; HARRISON $^{51}$, 1995; SHAY $\left.^{94}, 2000\right)$.

Um método alternativo consiste no desenvolvimento de sistemas mecânicos de higiene, como os equipamentos que empregam energia sônica ou eletrosônica para limpeza de próteses totais. O ultra-som consiste em meio rápido e efetivo de limpeza de instrumentais (PALENIK; MILLER ${ }^{79}$, 1984), sendo, coadjuvante importante no controle da contaminação cruzada. Tais aparelhos são comumente encontrados em hospitais, asilos e escolas odontológicas.

Sendo assim, esse trabalho objetivou avaliar a eficácia do uso de pastilhas efervescentes (método químico) e do ultra-som (método mecânico) de forma associada à 
escovação diária de próteses totais. Foram selecionadas escovas específicas por serem efetivas na remoção do biofilme (FERNANDES et al. ${ }^{42}$, 2006; SILVA-LOVATO; PARANHOS ${ }^{97}$, 2006).

A análise estatística empregada (Teste de Kruskal-Wallis) indicou haver diferença entre os métodos (tabela 2). Analisando as porcentagens das áreas recobertas pelo biofilme (tabela 1), as médias para o grupo controle (escovação com água) podem ser consideradas altas, sendo que 9 pacientes (45\%) tinham acima de 40\% de área recoberta pelo biofilme. Esses resultados eram previstos, pois a escovação com água favorece o acúmulo de biofilme (FERNANDES et al. ${ }^{42}$, 2006). O que chama a atenção é o fato de 5 pacientes apresentarem baixas porcentagens de biofilme (menores que 20\%). Fernandes et al. ${ }^{42}$ (2006) e Salles et al. ${ }^{89}$ (2006), em pesquisas sobre métodos de higiene de dentaduras, também encontraram baixos níveis de biofilme em grupos controles estabelecidos com enxágüe e escovação com água, respectivamente. Provavelmente, tais pacientes não obedeceram as instruções fornecidas pelos pesquisadores.

Em alguns estudos, onde foram comparados com grupos controles constituídos de água, os higienizadores químicos apresentaram efetividade limitada (KENG; LIM³ , 1996; NICHOLSON; STARK; SCOTT ${ }^{76}$, 1968). Assim como Sheen e Harrison ${ }^{95}$ (2000) e Paranhos et al. $^{82}$ (2007a), que em experimentos clínicos padronizados encontraram efetividade da imersão em peróxidos e em polímeros de silicone, respectivamente, nosso trabalho mostrou que o método de imersão em peróxido alcalino foi efetivo na remoção de biofilme dos aparelhos protéticos, mesmo sendo utilizado em um período de imersão diário de apenas 5 minutos (seguindo instruções do fabricante). A tabela 3 mostra que o grupo que empregou o método químico (pastilhas efervescentes), apresentou melhora na remoção de biofilme (tabela 3) e esta melhora foi significativa (tabela 4). Pela tabela 1, neste grupo, 12 pacientes (60\%) 
apresentaram baixos níveis de biofilme (abaixo de 20\%) e apenas 03 (15\%) apresentaram porcentagens acima de $40 \%$.

Estudos de higienizadores de próteses totais indicam uma considerável variação na efetividade dos vários produtos em relação à remoção de biofilme, manchas e cálculos (BUDTZ-JØRGENSEN ${ }^{25}$, 1979). Em alguns estudos, higienizadores comercialmente disponíveis, como o Steradent e o Corega Tabs foram tidos como eficazes (BUDTZJØRGENSEN; KELSTRUP ${ }^{22}$, 1977; NEILL ${ }^{75}$, 1968). Porém, ambos os estudos não podem ser considerados totalmente confiáveis, uma vez que não foram instituídos grupos placebo; além disso, não foram utilizados soluções evidenciadoras, para melhor avaliação e quantificação do biofilme.

Uma maior efetividade dos agentes químicos pode ser alcançada com a adição de um agente quelante (MacCALLUM; STAFFORD; MacCULLOCH ${ }^{65}$, 1968), ou de enzimas nas soluções (BUDTZ-JØRGENSEN ${ }^{21}$, 1977; BUDTZ-JØRGENSEN; KELSTRUP ${ }^{22}$, 1977). Quando comparados com soluções enzimáticas (CONNOR; SCHOENFELD; TAYLOR ${ }^{32}$, 1977; MINAGI et al. $^{66}$, 1987) ou mesmo com soluções contendo ácido sulfâmico (MANDERSON; BROWN ${ }^{59}$, 1978), soluções de peróxidos alcalinos convencionais mostraram-se menos efetivos. Em estudo clínico (BUDTZ-JØRGENSEN; KELSTRUP; POULSEN ${ }^{26}$, 1983), foi observado que uma solução enzimática contendo alcalase foi tão efetiva quanto a escovação, e que o uso do método associado (higienizador enzimático e escovação) apresentou melhores resultados.

Tem sido enfatizado que, para controle do biofilme, é necessário que o método de imersão seja complementado com a escovação, quer seja fornecendo instruções detalhadas ao paciente do método a ser seguido, ou mesmo por meio da limpeza realizada pelo profissional (KENG; LIM ${ }^{53}$, 1996). Porém, quando comparados com a escovação, os estudos relacionados à capacidade de remoção de biofilme, mostram resultados variados, com superioridade do 
método químico (McCABE; MURRAY; KELLY ${ }^{63}$, 1995), da escovação com pastas específicas (MUHLER; STOOKEY; HASSELL ${ }^{71}$, 1969; TARBET et al. ${ }^{100}$, 1984) ou gel de clorexidina (BUDTZ-JØRGENSEN; KNUDSEN ${ }^{24}$, 1978), ou do método associado (COBARGAS; CRUZAT; MIERZO² ${ }^{31}$ 2001; PARANHOS et al. ${ }^{82}$, 2007a).

Analisando o fato efetividade, um item que deve ser considerado, refere-se ao período de imersão empregado. Neste trabalho, o paciente foi orientado a seguir as instruções do fabricante, ou seja, imersão do aparelho protético na solução por 5 minutos 1 vez ao dia. Trabalhos anteriores indicaram que períodos curtos de imersão em higienizadores químicos não são efetivos (AUGSBURGER; ELAHI ${ }^{15}$, 1982; BUDTZ-JØRGENSEN ${ }^{21}$, 1977; HUTCHINS; PARKER ${ }^{50}$, 1973), sendo que uma maior efetividade pode ser alcançada se um período de imersão prolongado (“overnigth”) for usado (CONNOR; SCHOENFELD; TAYLOR ${ }^{32}$, 1977; SHANNON; McCRARY; STARCKE ${ }^{92}$, 1976). Apesar de usuários de próteses totais serem relutantes em remover seus aparelhos, mesmo durante o período do sono, torna-se importante um estudo clínico com emprego de período de imersão prolongado para verificação da possibilidade de aumento da efetividade desses produtos de imersão.. O emprego de imersões diárias adicionais (3 vezes ao dia) pode ser uma alternativa, porém o fator custo deve ser analisado.

Os resultados mostraram que, com o uso do ultra-som, houve diminuição dos níveis de biofilme (tabela 3) e que esta diminuição também foi significativa em relação ao controle (tabela 4). Pela tabela 1, neste grupo, 15 pacientes (75\%) apresentaram baixos níveis de biofilme (abaixo de 20\%) e apenas 1 apresentou porcentagem acima de 40\%. Esta igualdade estatística entre ambos os métodos (químico e mecânico) mostrou que o uso do ultra-som, isoladamente, alcança os mesmos resultados que o uso diário da pastilha e que a incorporação de um agente auxiliar, foi suficiente para uma melhora da remoção de biofilme. 
Trabalhos mostraram superioridade do ultra-som em relação a soluções de peróxidos alcalinos $\left(\mathrm{ABELSON}^{1}\right.$, 1981; GWINETT; CAPUTO ${ }^{47}$, 1983; PALENIK; MILLER ${ }^{79}$, 1984; RAAB et al. ${ }^{86}$, 1991) indicando que a ação de limpeza está relacionada somente à cavitação ulrasônica e não propriamente às soluções químicas. Porém, nestes trabalhos o aparelho foi empregado diariamente. Gwinnett e Caputo ${ }^{47}$ (1983) empregaram microscopia eletrônica de varredura para avaliar a superfície da resina acrílica e remoção da microbiota de dentaduras recém-confeccionadas e inoculadas com o $S$. mutans. O ultra-som foi mais efetivo que soluções de peróxido alcalino (Efferdent e Polident), porém, os autores salkientaram que suas conclusões eram limitadas pela natureza “in vitro” do estudo, reconhecendo que o biofilme formado "in vivo" pode exibir diferenças microbianas, quando comparado com o biofilme formado "in vitro”, chamando a atenção para a necessidade de estudos clínicos comparativos.

Nicholson, Stark e Scott $^{76}$ (1968), em estudo clínico, mostraram superioridade de soluções químicas em relação ao ultra-som, porém a solução utilizada foi hipoclorito de sódio. Tal superioridade pode estar relacionada ao alto pH e à constituição do hipoclorito de sódio. Porém, seu poder limitado sobre cálculos e efeitos corrosivos sobre metais contra-indicam seu uso por tempo prolongado (BACKENSTOSE; WELLS ${ }^{16}$, 1977). Produtos caseiros, como o Clorox-Calgon, são indicados por serem relativamente baratos, apesar do odor desagradável e do perigo de contaminação das mãos e danificação de vestuários. Sendo assim, estudos clínicos devem ser realizados para avaliar a propriedade de remoção de biofilme de soluções caseiras de hipoclorito de sódio, associados ou não ao ultra-som. Tais estudos são importantes, uma vez que trabalhos demonstram superioridade de higienizadores à base de hipoclorito alcalino, quando comparados com os peróxidos alcalinos (GHALICHEBAF; GRASER; ZANDER ${ }^{44}$, 1982; HUTCHINS; PARKER ${ }^{50}$, 1973; NICHOLSON; STARK; $\mathrm{SCOTT}^{76}$, 1968; SHANNON; STARCKE, 1978), mesmo quando os peróxidos são empregados em períodos prolongados de imersão (RUSTOGI et al. ${ }^{88}$, 1979). 
Um fato que chamou a atenção foi que, embora o uso do método combinado tenha proporcionado uma maior redução dos níveis de biofilme (tabela 3), as médias obtidas foram consideradas estatisticamente iguais aos grupos que utilizaram os métodos de forma isolada (tabela 4). Em nosso trabalho, o aparelho ultrasônico foi empregado com água destilada e somente ao final do período experimental, ou seja, uma única aplicação após 21 dias. Possivelmente, seu emprego diário, ou mesmo, com a incorporação de soluções químicas específicas, poderia originar melhores resultados, quando comparado ao método químico isolado.

A ação antimicrobiana dos produtos não foi analisada neste trabalho. Estudos comparativos microbiológicos concluíram que a realização de uma higiene adequada é obtida pela associação dos métodos químicos (imersão) e mecânico (escovação) (CHAN et al. ${ }^{29}$, 1991; LEE et al. ${ }^{57}$, 1985; SESMA et al. ${ }^{91}$, 1999). Sendo assim, experimentos microbiológicos avaliando a efetividade da associação da imersão ao ultra-som se fazem necessárias. O estudo da ação antimicrobiana de produtos de imersão à base de peróxido alcalino associados ou não ao ultra-som é projeto de futuros estudos, uma vez estabelecido o método para análise. 


\section{CONCLUS $\tilde{A} O$}


Pela análise dos dados obtidos pôde-se concluir que:

Houve igualdade entre os 3 métodos empregados (químico, mecânico e associado), sendo que todos os métodos foram considerados superiores ao controle estabelecido (escovação com água). Os métodos químico (imersão em pastilha efervescente de peróxido alcalino) e mecânico (agitação ultrasônica) podem ser empregados como métodos auxiliares de higiene, contribuindo para a manutenção da saúde oral de usuários de próteses totais. 
REFEREATNCIAS BIBLIOGRÁFICAS 
1. ABELSON, D. C. Denture plaque and denture cleansers. J. Prosthet. Dent., St Louis, v.45, n.4, p.376-9, April, 1981.

2. ABELSON, D. C. Denture plaque and denture cleansers: Review of the literature. Gerodontics, Copenhagen, v.1, n.5, p.202-6, June, 1985.

3. ABERE, D. J. Post-placement care of complete and removable partial dentures. Dent. Clin. North. Am., Philadelphia, v.23, n.1, p.143-51, January, 1979.

4. ABRAMSON, A. L.; PRYOR, W. H.; EASON, R. L.; MESSER, E. J. Corro-sive injury of the oral cavity and esophagus caused by some denture cleanser powders. Ann. Otol. Rhinol. Laryngol., St Louis, v.83, n.6, p.714-9, November-December, 1974.

5. ABRAMSON, A. L.; EASON,R. L.; PRYOR,W. H.; MESSER, E. J. Upper digestive tract burns caused by Denalan ${ }^{\circledR}$ denture cleanser powder. Ann. Otol. Rhinol. Laryngol., St Louis, v.84, n.1, p.102-6, January-February, 1975.

6. ABRAMSON, A. L. Corrosive injury of the esophagus. Result of ingesting some denture cleanser tablets and powder. Arch. Otolaryngol., Chicaco, v.104, n.9, p. 514-6, September, 1978.

7. ADVERTISING AGE, n.18, p.26, December, 1978.

8. AKPAN, A.; MORGAN, R. Oral candidiasis. Postgrad. Med. J., London, v.78, n.922, p.455-9, August, 2002.

9. AMBJØRNSEN, E.; VALDERHAUG, J.; NORHEIM, P. W.; FLØYSTRAND, F. Assessment of an additive index for plaque accumulation on complete maxillary dentures. Acta Odontol. Scand., Oslo, v.40, n.4, p.203-8, June, 1982.

10. AMBJØRNSEN, E.; RISE, J. HAUGEJORDEN, O. A study of examiner errors associated with measurement of denture plaque. Acta Odontol. Scand., Oslo, v.42, n.3, p.183-91, June, 1984.

11. AMBJØRNSEN, E.; RISE, J. The effect of verbal information and demonstration on denture hygiene in elderly people. Acta Odontol. Scand., Oslo, v.43, n.1, p.19-24, March, 1985.

12. AMERICAN DENTAL ASSOCIATION, GUIDE TO DENTAL MATERIALS AND DEVICES, ed 6, pp 152-153, Chicago, 1974-1975.

13. ANTHONY, D. H.; GIBBONS, P. The nature and behaviour of denture cleanser. J. Prosthet. Dent., St Louis, v.8, n.5, p.796-810, September-October, 1958.

14. ARAB, J.; NEWTON, J. P.; LIOYD, C. H. The importance of water tempera-ture in denture cleaning procedures. J. Dent., Guildford, v.16, n.6, p.277-81, July, 1988.

15. AUGSBURGER, R. H; ELAHI, J. M. Evaluation of seven proprietary denture cleansers. J. Prosthet. Dent., St Louis, v.47, n.4, p.356-9, April, 1982. 
16. BACKENSTONE, W. M.; WELLS, J. G. Side effects of immersion-type cleansers on the metal components of dentures. J. Prosthet. Dent., St. Louis, n.37, p.616, 1977.

17. BARCLAY, G. R.; FINLAYSON, N. D. C. Severe oesophageal injury caused by Steradent. Postgrad. Med. J., London, v.61, n.714, p.335-6, April, 1985.

18. BASSON, N. J.; QUICK, A. N.; THOMAS, C. J. Household products as sanitising agents in denture cleansing. J. Dent. Assoc. S. Afr., Johnnesburg, v.47, n.10, p.437-9, October, 1992.

19. BATES, J. F.; SMITH, D. C. Evaluation of indirect resilient liners for denture: laboratorial and clinical tests. J. Amer. Dent. Assoc., Chicago, v.70, n.2, p.344-53, February, 1965.

20. BECK, H. O. Denture cleansers and retaining devices. J. Am. Pharm. Assoc., Washington, v. 13, n. 5, p. 246-7, September, 1973.

21. BUDTZ-JØRGENSEN, E. Prevention of denture plaque formation by an enzyme denture cleanser. Jour. Biol. Buccale, Paris, v.5, n.3, p.239-44, Sepember, 1977.

22. BUDTZ-JØRGENSEN, E.; KELSTRUP, J. Enzyme as denture cleansers. Scand. J. Dent. Res., Copenhagen, v.85, n.3, p.209-15, March, 1977.

23. BUDTZ-JØRGENSEN, E. A 3-months' study of enzymes as denture cleansers. J. Oral Rehabil., Oxford, v.5, n.1, p.35-9, January, 1978.

24. BUDTZ-JØRGENSEN, E.; KNUDSEN, A. M. Chlorhexidine gel and Stera-dent ${ }^{\circledR}$ employed in cleaning dentures. Acta Odontol. Scand., Oslo, v.36, n.2, p.83-7, August, 1978.

25. BUDTZ-JØRGENSEN, E. Materials and methods for cleaning dentures. J. Prosthet. Dent., St Louis, v.42, n.6, p.619-23, Dec. 1979.

26. BUDTZ-JØRGENSEN, E.; KELSTRUP, J.; POULSEN, S. Reduction of for-mation of denture plaque by a protease (Alcalase ${ }^{\circledR}$ ). Acta Odontol. Scand., Oslo, v.41, n.2, p. 93-8, April, 1983.

27. BUDTZ-JØRGENSEN, E.; ATTSTRÖM, R. The effect of Octapinol ${ }^{\circledR}$, a substance with low antibacterial activity, on denture plaque and denture-induced stomatitis. Clin. Prev. Dent., Philadelphis, v.6, n.1, p.23-27, January-February, 1984.

28. BUDTZ-JØRGENSEN, E.; MOJON, P.; RENTSCH, A.; DESLAURIERS, N. Effects of an oral health program on the occurrence of oral candidosis in a long-term care facility. Community Dent. Oral Epidemiol., Copenhagen, v.28, n.2, p.141-9, April, 2000.

29. CHAN, E.C.S.; IOGOVAZ, I.; SIBOO, R.; BILYK, M.; BAROLET, R.; AMSEL, R.; WOOLEY, C.; KLITORINOS, A. Comparison of two popular methods for removal and killing of bacteria from dentures. J. Can. Dent. Assoc., Canadá, v.57, n.12, p.937-9, December, 1991. 
30. COBARGAS, J.M.; CRUZAT, C.P.; MIERZO, H.P. Efficacy of prótesis chemical cleanser: clinical and in vitro study. Rev. Fac. Odontol. Univ. Chile., Chile, n.15, p.28-34, 1997.

31. COBARGAS, J.M.; CRUZAT, C.P.; MIERZO, H.P. Eficacia de limpiador quimico de protesis. Estudo clinico e in vitro. Rev. Odontol. Chile, Chile, v.15, n.1, p.1-7, 2001.

32. CONNOR, J. N. E.; SCHOENFELD, C. M.; TAYLOR, R. L. An evaluation of an enzyme denture cleanser. J. Prosthet. Dent., St Louis, v.37, n.2, p.147-57, February, 1977.

33. COUNCIL ON DENTAL MATERIALS, INSTRUMENTS AND EQUIP-MENT. Denture cleansers. J. Am. Dent. Assoc., Chicago, v.106, n.1, p.77-9, January, 1983.

34. CRAWFORD, C-A.; NEWTON, J. P.; YEMM, R. Misuse of a denture clea-ning agents. J. Dent. Res., Washington, v.64, n.2, p.673, Abstract 92, April, 1985.

35. CRAWFORD, C-A.; LLOYD, C. H.; NEWTON, J., P.; YEMM, R. Denture bleaching: a laboratory simulation of patients' cleaning procedures. J. Dent., Guildford, v.14, n.6, p. 258-61, 1986.

36. CRAWFORD, C-A.; NEWTON, J. P.; YEMM, R. Bleached dentures: misuse of a denture-cleaning agent. Dent. Update, Guildford, v.14, n.1, p.29-32, January-February. 1987.

37. CUMMING, C. G.; WIGHT C.; BLACKWELL, C. L.; WRAY, D. Denture stomatitis in the elderly. Oral Microbiol. Immunol., Copenhagen, v.5, n.2, p.82-5, April, 1990.

38. DAVENPORT, J. C.; HAMMOND, P. The acquisition and validation of removable partial denture design knowledge. I. Methodology and overview. J. Oral Rehabil., Oxford, v.23, n.3, p.152-7, March, 1996.

39. DEPAOLA, L. G.; MINAH, G. E.; ELIAS, S. A. Evaluation of agents to reduce microbial growth on dental prostheses of myelosuppressed cancer patients. Clin. Prevent. Dent., Philadelphia, v.6, n.2, p.9-12, March-Aprril, 1984.

40. DILLS, S. S.; OLSHAN, A. M.; GOLDNER, S.; BROGDON, C. Comparison of the antimicrobial capability of na abrasive paste and chemical-soak denture cleaners. $\mathbf{J}$. Prosthet. Dent., St Louis, v.60, n.4, p.467-70, October, 1988.

41. DYER, D.; MacDONALD, E.; NEWCOMBE, R.G.; SCRATCHER, C.; LEY, F.; ADDY, M. Abrasion and stain removal by different manual toothbrushes and brush actions: studies in vitro. J. Clin. Periodontol., Copenhagen, v.28, n.2, p.121-127, February, 2001.

42. FERNANDES RAG, SILVA-LOVATO CH, PARANHOS HFO, ITO IY. Eficácia de escovas para próteses totais: propriedade de remoção de biofilme e ação antimicrobiana. Braz. Oral Res., v. 20, p.252, 2006. 
43. FERRAN, P.; MIGUEL, J. L.; BOUSQUET, A.; DUBOIS, J. Hygiène et prophylaxie en prothèse dentaire complète chez la personne âgée. Inf. Dent., Paris, v.66, n.15, p.150915, Aprril, 1984.

44. GHALICHEBAF, M.; GRASER, G. N.; ZANDER, H. A. The efficacy of denturecleansing agents. J. Prosthet. Dent., St Louis, v.48, n.5, p.515-520, November, 1982.

45. GORNITSKY, M.; PARADIS, I.; LANDAVERDE, G.; MALO, A-M.; VELLY, A.M. A clinical and microbiological evaluation of denture cleansers for geriatric patients in long-term care institutions. J. Can. Dent. Assoc., Canadá, v.68, n.1, p.39-45, January, 2002.

46. GREEN, SL. Anaerobic pleuro-pulmonary infections. Postgrad. Med., v.65, p.62-66, 1979.

47. GWINNETT, A. J.; CAPUTO, L. The effectiveness of ultrasonic denture cleaning: A scanning electron microscope study. J. Prosthet. Dent., St louis, v.50, n.1, p.20-5, July, 1983.

48. HASELDEN, C. A.; HOBKIRK, J. A.; PEARSON, G. J.; DAVIES, E. H. A comparison between the wear resitance of three types of denture resin to three different dentifrices. J. Oral Rehabil., Oxford, v.25, n.5, p.335-339, May, 1998.

49. HOAD-HEDDICK, G.; GRANT, A. A.; GRIFFITHS, C. S. Investigation into the cleanliness of dentures in an elderly population. J. Prosthet. Dent., St Louis, v.64, n.1, p. 48-52, July, 1990.

50. HUTCHINS, D. W.; PARKER, W. A. A clinical evaluation of the ability of denture cleaning solutions to remove dental plaque from prosthetic devices. N. Y. State D. J., New York, v. 39, p. 363-7, June-July. 1973.

51. JAGGER, D. C.; HARRISON, A. Denture cleansing-the best approach. Br. Dent. J., London, v.178, n.11, p.413-7, June 10, 1995.

52. JEGANATHAN, S.; THEAN, H. P.; THONG, K. T.; CHAN, Y. C.; SINGH, M. A clinically viable index for quantifying denture plaque. Quintessence Int., Berlim, v.27, n.8, p.569-73, August, 1996.

53. KENG, S-B.; LIM, M. Denture plaque distribution and the effectiveness of a perborate-containing denture cleanser. Quintessence Int., Berlim, v.27, n.5, p.341-5, May, 1996.

54. KULAK, Y.; ARIKAN, A.; ALBAK, S.; OKAR, I.; KAZAZOGLU, E. Scanning electron microscopic examination of different cleaners: surface contaminant removal from dentures. J. Oral Rehabil., Oxford, v.24, n.3, p.209-15, March, 1997.

55. KULAK-OZKAN, Y.; KAZAZOLU, E.; ARIKAN, A. Oral hygiene habits, denture cleanliness, presence of yeasts and stomatitis in elderly people. J. Oral Rehabil., Oxford, v.29, n.3, p.300-4, March, 2002. 
56. LANGWELL, W. H. The cleansing of artificial dentures. Br. Dent. J., London, v.15, n.11, p.337-9, November, 1955.

57. LEE, H. E.; WANG, C. C.; WANG, J. C.; CHEN, C. P. the effect of denture cleansers and cleaning methods on the microflora of denture plaque. Kaohsivng-Hsueh Ko Hsueh, v.1, n.2, p.88, Feb. 1985.

58. MACKENZIE, I. J. A denture-cleansing tablet swallowed. (letter). Br. Dent. J., London, v.153, n.1, p.6-7, July 6, 1982.

59. MANDERSON, R.D.; BROWN, D. A clinical and laboratorial investigation of a new denture cleaner*. J. Dent., Guildford, v.6, n.3, p.222-8, September, 1978.

60. MARCHINI, L.; TAMASHIRO, E.; NASCIMENTO, D. F. F.; CUNHA, V. P. Selfreported denture hygiene of sample of edentulous attendess at a University dental clinic and the relationship to the condition of the oral tissues. Gerodontology, Oxford, v.21, n.4, p.226-8, December, 2004.

61. MARCHINI, L.; VIEIRA, P. C.; BOSSAN, T. P.; MONTENEGRO, F. L.; CUNHA, V. P. Self-reported oral hygiene habits among institutionalized elderly and their relationship to the condition of oral tissue in Taubate, Brasil. Gerodontology, Oxford, v.23, n.1, p.33-7, March, 2006.

62. MARTIN, B. J.; CORLEW, M. M.; WOOD, H.; OLSON, D.; GOLOPOL, L. A.; WINGO, M.; KIRMANI, N. The association of swalloeing dysfunction and aspiration pneumonia. Dysphagia, v.9, p.1-6, 1994.

63. McCABE, J. F.; MURRAY, I. D.; KELLY, P. J. The efficacy of denture cleansers. Eur. J. Prosthodont. Restor. Dent., Larkfield, v.3, n.5, p.59-64, September, 1995.

64. McCABE, J. F.; MURRAY, I. D.; LAURIE, J.; KELLY, P. J. A method for scoring denture plaque. Eur. J. Prosthodont. Restor. Dent., Larkfield, v.4, n.2, p.59-64, June, 1996.

65. McCALLUM, M.; STAFFORD, G. T.; MacCULLOCH, W. T. Wich clean-ser? A report on a survey of denture cleansing routine and the development of a new denture cleanser. Dent. Pract., Bristol, v.19, n.3, p.83-9, November, 1968.

66. MINAGI, S.; TSUNODA, T.; YOSHIDA, K.; TSURU, H. Objective testing of the efficiency of denture-cleansing agents. J. Prosthet. Dent., St Louis, v.58, n.5, p.595-8, November, 1987.

67. MOORE, T. C; SMITH, D. E.; KENNY, G. E Sanitization of dentures by several denture hygiene methods. J.Prosthet. Dent., St. Louis, v.52, n.2, p.158-63, 1984.

68. MOSKONA, D.; KAPLAN, I. Oral lesions in elderly denture weares. Clin. Prevent. Dent., Philadelphia, v.14, n.5, p.11-14, September-October, 1992.

69. MUELLER, H. J.; GREENER, E. H. Characterization of some denture cleansers. J. Prosthet. Dent., St. Louis, v. 43, n. 5, p. 491-6, May, 1980. 
70. MUENCHINGER, F. S. Evaluation of an eletrosônica denture cleanser. J. Prosthet. Dent., St. Louis, n.33, p.610, 1975.

71. MUHLER, J. C.; STOOKEY, G. K.; HASSELL, T. M. The development and evaluation of na improved denture cleaning and polishing paste. J. Indiana State Dent. Assoc., New Delhi, v.48, n.1, p.17-27, January, 1969.

72. MURRAY, I. D.; McCABE, J. F.; STORER, R. Abrasivity of denture cleaning pastes in vitro and in situ. Br. Dent J., London, v.161, n.4, p.137-41, August 23, 1986.

73. MURTOMAA, H.; MEURMAN, J. H. Mechanical aids in the prevention of dental diseases in the elderly. Int. Den. J., Guildford, v.42, n.5, p.365-72, October, 1992.

74. MYERS, H. M.; KROL. A. J. Effectiveness of a sonic-action denture cleaning program. J. Prosthet. Dent., St Louis, v.32, n.6, p.613-8, December, 1974.

75. NEILL, D. J. A study of materials and methods employed in cleaning dentures. Br. Dent. J., London, v.124, n.3, p.107-15, February, 1968.

76. NICHOLSON, R. J.; STARK, M. M.; SCOTT, H. E. Calculus and stain removal from acrylic resin dentures. J. Prosthet. Dent., St Louis, v.20, n.4, p.326-9, October, 1968.

77. NIKAWA, H.; HAMADA, T.; YAMASHIRO, H.; KUMAGAI, H. A review of in vitro and in vivo methods to evaluate the efficacy of denture cleansers. Int. $\mathbf{J}$. Prosthodont., Lombard, v.12, n.2, p.153-19, March- April, 1999.

78. ÖDMAN, P. A. The effectiveness of an enzyme-containing denture cleanser. Quintessence Int., Berlim, v.23, n.3, p.187-90, March, 1992.

79. PALENIK, C. J.; MILLER, C. H. In vitro testing of three denture-cleaning systems. J. Prosthet. Dent., St. Louis, v.51, n.6, p.751-4, July, 1984.

80. PARANHOS, H. F. O.; LARA, E. H. G.; PANZERI, H.; CANDIDO, R. C.; ITO, I. Y. Capacity of denture plaque/biofilm removal and antimicrobial action of a new denture paste. Braz. Dent. J., Ribeirão Preto, v.11, n.2, p.97-104, 2000.

81. PARANHOS, H. F. O.; SILVA, C. H. Comparative study of methods for the quantification of biofilm on complete dentures. Braz Oral Res., v.18, n.3, p.215-23, JulySeptember, 2004.

82. PARANHOS, H.F.O.; SILVA-LOVATO, C.H.; SOUZA, R.F.; CRUZ, P.C.; FREITAS, K.M.; PERACINI, A. Effects of mechanical and chemical methods on denture biofilm accumulation. J. Oral Rehabil., Oxford, n.34, p.606-12, 2007a.

83. PARANHOS, H.F.O.; SILVA-LOVATO, C.H.; VENEZIAN, G.C.; MACEDO, L.D.; SOUZA, R.F. Distribution of biofilm on internal and external surfaces of upper complete dentures: the effect of hygiene instruction. Gerodontology, Sothwest Harbor, v.24, n.3, p.162-8, 2007b. 
84. PIETROKOVSKY, L.; AZUELOS, J.; TAU, S.; MOSTAVOY, R. Oral findings in elderly nursing home residents in selected countries: oral hygiene conditions and plaque accumulation on denture surfaces. J. Prosthet. Dent., St. Louis, v.73, n.2, p.136-41, February, 1995.

85. PURNAVEJA, S.; FLETCHER, A. M.; RITCHIE, G. M.; AMIN, W. M.; MORADIANS, S.; DODD, A. W. Compatibility of denture cleansers with some new self curing denture base materials. Biomaterials, Guildford, v.3, n.4, p.251-2, October, 1982.

86. RAAB, F. J.; TAYLOR, C. A.; BUCHER, J. A.; MANN, B. L. Scanning electron microscopic examination of ultrasonic and effervescent methods of surface contaminant removal from complete dentures. J. Prosthet. Dent., St Louis, v.65, n.2, p.255-8, February, 1991.

87. ROBINSON, J. G.; McCABE, J. F.; STORER, R. The whitening of acrylic dentures: The role of denture cleansers. Br. Dent. J., London, v.159, n.8, p.247-50, October 19, 1985.

88. RUSTOGI, K. N.; MELLBERG, J. R.; SCHLISSEL, H. J.; HANSEN, K. R.; VOLPE, A. R. The clinical efficacy of denture cleansers. Q. Natl. Dent. Assoc., Los Angeles, v.37, n.3, p.100-6, April, 1979.

89. SALLES, A. E. S.; MACEDO, L. D.; FERNANDES, R. A. G.; SILVA-LOVATO, C. H.; PARANHOS, H. F. O. Avaliação dos níveis de biofilme em próteses totais com uso de agentes higienizadores e saliva artificial. Braz. Oral Res., v. 20, p.250, 2006.

90. SATOH, Y.; OHTANI, K.; MAEJIMA, K.; MORIKAWA, M.; MATSUZU, M.; NAGAI, E.; TOYOMA, H.; OHWA, M.; OHKI, K.; KAKETANI, M.; NISHIYAMA, M. Wear of artificial denture teeth by use of toothbrushes. J. Nihon. Univ. Sch. Dent., Tokyo, v.32, p.247-58, 1990.

91. SESMA, N.; TAKADA, K. S.; LAGANÁ, D. C. JAEGER, R. G.; AZMBUJA Jr., N. Eficiência de métodos caseiros de higienização e limpeza de próteses parciais removíveis. Rev. Assoc. Paul. Cir. Dent., São Paulo, v.53, n.6, p.463-8, novembro-dezembro, 1999.

92. SHANNON, I.L.; McCRARY, B.R.; STARCKE, E.N. Removal of salivary deposits by commercial denture cleansers. Gen. Dent., Chicago, v.24, n.6, p.30-4, NovemberDecember, 1976.

93. SHANNON, I. L.; STARCKE, E. N. Higher performance denture cleansers. N. Y. J. Dent., New York, v.48, n.8, p.246-50, October, 1978.

94. SHAY, K. Denture Hygiene: A Review and Update. The Journal of Contemporary Dental Practice, v. 1, n. 2, Winter Issue, 2000.

95. SHEEN, S.R.; HARRISON, A. Assessment of plaque prevention on dentures using an experimental cleanser. J. Prosthet. Dent., St. Louis, v.84, n.6, p.594-601, December, 2000. 
96. SILVA, C. H.; PARANHOS, H. F. O.; ITO, I. Y. Biofilm disclosing agents in complete denture: clinical and antimicrobial evaluation. Pesqui. Odontol. Bras., São Paulo, n.16, p.270-75, 2002.

97. SILVA-LOVATO, C. H.; PARANHOS, H. F. O. Efficacy of biofilm disclosing agents and three brushes in the control f complete denture cleansers. J. Appl. Oral Sci., n.14, p.454-59, 2006.

98. SMITH, D. C. The cleansing of dentures. Dent. Pract. Dent. Rec., Bristol, v.17, n.2, p 39-43, October, 1966.

99. SMITH, J. M.; SHEIHAM, A. How dental conditions handicap the elderly community dent oral epidemiol. Comm. Dent. Oral Epidemiol., Copenhagen, v.7, n.6, p.305-10, 1979.

100. TARBET, W. J.; AXELROD, S.; MINKOFF, S.; FRATARCANGELO, P. A. Denture cleansing: a comparison of two methods. J. Prosthet. Dent., St Louis, v.51, n.3, p.322-5, March, 1984.

101. TEMER, K.; STIPETIC, D.; CEKIC-ARAMBASIN, A.; KRALJEVIC, K. Utjecaj Sredstva za ciscenje proteze na kvasnice protezne baze. Acta Stomatol. Croat., SerboCroatioan, v.25, n.2, p.91-6, 1991.

102. THEILADE, J. Om rengøring af proteser. Tandlaegebladet, Copenhagen, v. 62, p.41, 1958.

103. WAGNER, A. G. Maintenance of the partially edentulous mouth and care of the denture. Dent. Clin. North Am., Philadelphia, n.17, p.755-68, 1973.

104. WALKER, D.M.; STAFFORD, G.D.; HUGGETT, R.; NEWCOMBE, R.G. The treatment of denture-induced stomatitis. Evaluation of two agents. Br. Dent. J., London, v.151, n.12, p.416-9, December, 1981.

105. WENDT, D.C. How to promote and maintain good oral health in spite of wearing dentures. J. Prosth. Dent., St. Louis, v.53, n.6, p.805-6, June, 1985. 
APÊNDICES 


\section{Apêndice A}

Tabela A1 - Área total, área de biofilme e porcentagem de biofilme nas superfícies internas das próteses totais superiores após o uso de cada método de higiene testado.

\begin{tabular}{|c|c|c|c|c|c|}
\hline $\mathbf{P}$ & & Controle & Químico & Mecânico & Associado \\
\hline \multirow{3}{*}{1} & AT & 23,60 & 20,12 & 18,44 & 18,48 \\
\hline & $\mathrm{AB}$ & 9,70 & 7,84 & 7,68 & 2,97 \\
\hline & $\%$ & 41,10 & 38,96 & 41,64 & 16,07 \\
\hline \multirow{3}{*}{2} & AT & 25,18 & 16,83 & 17,02 & 22,95 \\
\hline & $\mathrm{AB}$ & 7,42 & 3,17 & 1,22 & 0,68 \\
\hline & $\%$ & 29,46 & 18,83 & 7,16 & 2,96 \\
\hline \multirow[t]{3}{*}{3} & AT & 20,21 & 23,44 & 23,73 & 18,82 \\
\hline & $\mathrm{AB}$ & 11,04 & 10,20 & 2,46 & 3,52 \\
\hline & $\%$ & 54,62 & 43,51 & 10,36 & 18,70 \\
\hline \multirow{3}{*}{4} & AT & 19,87 & 20,38 & 19,96 & 15,81 \\
\hline & $\mathrm{AB}$ & 7,31 & 6,49 & 4,93 & 6,61 \\
\hline & $\%$ & 36,78 & 31,84 & 24,69 & 41,80 \\
\hline \multirow{3}{*}{5} & AT & 23,63 & 29,02 & 28,36 & 19,73 \\
\hline & $\mathrm{AB}$ & 6,61 & 0,00 & 0,00 & 2,46 \\
\hline & $\%$ & 27,97 & 0,00 & 0,00 & 12,46 \\
\hline \multirow{3}{*}{6} & AT & 29,82 & 23,10 & 22,59 & 22,54 \\
\hline & $\mathrm{AB}$ & 4,10 & 1,49 & 1,73 & 6,41 \\
\hline & $\%$ & 13,74 & 6,45 & 7,65 & 28,43 \\
\hline \multirow{3}{*}{7} & AT & 23,85 & 17,67 & 18,67 & 16,89 \\
\hline & $\mathrm{AB}$ & 8,39 & 0,58 & 0,80 & 0,77 \\
\hline & $\%$ & 35,17 & 3,28 & 4,28 & 4,55 \\
\hline \multirow{3}{*}{8} & AT & 18,36 & 17,48 & 18,74 & 17,27 \\
\hline & $\mathrm{AB}$ & 2,87 & 3,28 & 2,62 & 4,69 \\
\hline & $\%$ & 15,63 & 18,76 & 13,98 & 27,15 \\
\hline \multirow{3}{*}{9} & AT & 25,83 & 21,91 & 21,70 & 22,19 \\
\hline & $A B$ & 13,13 & 0,00 & 1,75 & 0,00 \\
\hline & $\%$ & 50,83 & 0,00 & 8,06 & 0,00 \\
\hline \multirow{3}{*}{10} & AT & 25,27 & 22,24 & 20,14 & 16,94 \\
\hline & $\mathrm{AB}$ & 10,21 & 4,32 & 8,04 & 8,90 \\
\hline & $\%$ & 40,40 & 19,42 & 39,92 & 52,53 \\
\hline \multirow{3}{*}{11} & AT & 20,67 & 19,87 & 19,94 & 22,36 \\
\hline & $\mathrm{AB}$ & 8,98 & 7,12 & 7,77 & 1,94 \\
\hline & $\%$ & 43,44 & 35,83 & 38,96 & 8,67 \\
\hline \multirow{3}{*}{12} & AT & 23,51 & 16,98 & 19,73 & 22,82 \\
\hline & $\mathrm{AB}$ & 3,03 & 0,00 & 3,24 & 0,00 \\
\hline & $\%$ & 12,88 & 0,00 & 16,42 & 0,00 \\
\hline \multirow{3}{*}{13} & AT & 18,02 & 17,28 & 16,59 & 21,61 \\
\hline & $\mathrm{AB}$ & 11,21 & 3,39 & 2,65 & 0,11 \\
\hline & $\%$ & 62,20 & 19,61 & 15,97 & 0,50 \\
\hline \multirow{3}{*}{14} & AT & 23,41 & 24,45 & 22,81 & 18,54 \\
\hline & $\mathrm{AB}$ & 5,77 & 1,88 & 2,84 & 0,00 \\
\hline & $\%$ & 24,64 & 7,68 & 12,45 & 0,00 \\
\hline \multirow{3}{*}{15} & AT & 16,36 & 19,78 & 19,21 & 17,46 \\
\hline & $\mathrm{AB}$ & 12,97 & 4,64 & 3,06 & 0,22 \\
\hline & $\%$ & 79,27 & 23,45 & 15,92 & 1,26 \\
\hline \multirow{3}{*}{16} & AT & 24,36 & 26,16 & 24,74 & 18,17 \\
\hline & $\mathrm{AB}$ & 4,61 & 2,10 & 1,92 & 0,22 \\
\hline & $\%$ & 18,92 & 8,02 & 7,76 & 1,21 \\
\hline \multirow{3}{*}{17} & AT & 19,52 & 25,41 & 24,48 & 16,13 \\
\hline & $\mathrm{AB}$ & 4,31 & 6,42 & 2,95 & 2,53 \\
\hline & $\%$ & 22,07 & 25,26 & 12,05 & 15,68 \\
\hline 18 & AT & 23,87 & 21,97 & 21,26 & 15,63 \\
\hline & $\mathrm{AB}$ & 21,16 & 4,98 & 2,30 & 2,86 \\
\hline & $\%$ & 88,64 & 22,66 & 10,81 & 18,29 \\
\hline 19 & $\mathrm{AT}$ & 19,00 & 23,23 & 21,68 & 19,69 \\
\hline & $\mathrm{AB}$ & 13,78 & 7,49 & 4,53 & 1,24 \\
\hline & $\%$ & 72,78 & 32,24 & 20,89 & 6,29 \\
\hline
\end{tabular}




\begin{tabular}{ll|l|c|c|c|c|}
\hline $\mathbf{P}$ & & Controle & Químico & Mecânico & Associado \\
\hline $\mathbf{2 0}$ & AT & 32,01 & 22,20 & 21,85 & 18,88 \\
& AB & 5,29 & 5,23 & 1,21 & 1,16 \\
& $\%$ & 16,52 & 23,55 & 5,53 & 6,14 \\
\hline
\end{tabular}

$\mathbf{P}=$ Pacientes

$\mathrm{AT}=$ Área Total

$\mathrm{AB}=$ Área do Biofilme 
Apêndice B - Testes estatísticos para os resultados da porcentagem de higiene.

Tabela B1. Teste de aderência à curva normal - freqüências por intervalos de classe:

\begin{tabular}{l|l|c|c|c|c|c|c}
\hline Intervalos de classe & M-3s & M-2s & M-1s & Med. & M+1s & M+2s & M+3s \\
\hline Curva normal & 0.44 & 5.40 & 24.20 & 39.89 & 24.20 & 5.40 & 0.44 \\
Curva experimental & 0.00 & 2.50 & 35.00 & 40.00 & 13.75 & 7.50 & 1.25 \\
& & & & & & & \\
\hline
\end{tabular}

Tabela B2. Teste de aderência à curva normal - cálculo do Qui quadrado:

\begin{tabular}{l|l|l}
\hline Graus de liberdade & 4 & Interpretação \\
\hline $\begin{array}{l}\text { Valor do Qui quadrado } \\
\text { Probabilidade de Ho }\end{array}$ & 11.71 & $\begin{array}{c}\text { A distribuição amostral } \\
\text { testada não é normal. }\end{array}$ \\
\hline
\end{tabular}


ANEXO 1 - Filosofia do teste estatístico utilizado.

Teste de Kruskal-Wallis: É uma espécie de análise de variância para uma só variável e dados amostrais independentes. O teste não utiliza os valores numéricos diretamente, mas sim os postos que eles ocupam numa série de dados ordenados por valores crescentes, série essa que reúne num só conjunto os dados de todas as amostras que vão ser comparadas. Os dados são introduzidos amostra por amostra. Embora o teste tenha sido idealizado para testar um único fator de variação, parece viável utilizá-lo também em casos de mais de um critério de variação, desde que se faça a análise de um deles de cada vez, reunindo em grupos todos os dados que tenham em comum esse fator, considerando os demais como simples repetição. 